\title{
Composting and compost utilization: accounting of greenhouse gases and global
} warming contributions

Boldrin, Alessio; Andersen, Jacob Kragh; Møller, Jacob; Christensen, Thomas Højlund; Favoino, E.

Published in:

Waste Management and Research

Link to article, DOI:

$10.1177 / 0734242 \times 09345275$

Publication date:

2009

Document Version

Peer reviewed version

Link back to DTU Orbit

Citation (APA):

Boldrin, A., Andersen, J. K., Møller, J., Christensen, T. H., \& Favoino, E. (2009). Composting and compost utilization: accounting of greenhouse gases and global warming contributions. Waste Management and Research, 27(8), 800-812. https://doi.org/10.1177/0734242X09345275

\section{General rights}

Copyright and moral rights for the publications made accessible in the public portal are retained by the authors and/or other copyright owners and it is a condition of accessing publications that users recognise and abide by the legal requirements associated with these rights.

- Users may download and print one copy of any publication from the public portal for the purpose of private study or research.

- You may not further distribute the material or use it for any profit-making activity or commercial gain

- You may freely distribute the URL identifying the publication in the public portal 


\title{
Composting and compost utilization: Accounting of greenhouse gases and global warming contributions
}

\author{
Boldrin $^{1}$, A., Andersen ${ }^{1}$, J.K., Møller ${ }^{1}$, J., Favoino ${ }^{2}$, E. \& Christensen ${ }^{1}$, T.H. \\ ${ }^{1}$ Department of Environmental Engineering \\ Technical University of Denmark \\ Kongens Lyngby, Denmark \\ ${ }^{2}$ Scuola Agraria del Parco di Monza \\ Monza, Italy
}

"NOTE: this is the author's version of a work that was accepted for publication in Waste Management \& Research journal. Changes resulting from the publishing process, such as peer review, editing, corrections, structural formatting, and other quality control mechanisms may not be reflected in this document. Minor changes may have been made to this manuscript since it was accepted for publication. A definitive version is published in Waste Management \& Research, vol 27, pp 800-812, doi: 10.1177/0734242X09345275" 


\begin{abstract}
Greenhouse gas (GHG) emissions related to composting of organic waste and use of compost was assessed from a waste management perspective. The GHG accounting for composting includes use of electricity and fuels, emissions of methane and nitrous oxide from the composting process, and savings obtained by the use of the compost. The GHG account depends on waste type and composition (kitchen organics, garden waste), technology type (open systems, closed systems, home composting), the efficiency of off-gas cleaning at enclosed composting systems, and the use of the compost. The latter is an important issue and is related to the long term binding of carbon in the soil, to related effects in terms of soil improvement and to what the compost substitutes; this could be fertilizer and peat for soil improvement or for growth media production. The overall Global Warming Factor (GWF) for composting therefore varies between significant savings (-900 $\mathrm{kg} \mathrm{CO}_{2}$-equivalents tonne ${ }^{-1}$ wet waste (ww)) and a net load (300 kg CO 2 -equivalents tonne ${ }^{-1} \mathrm{ww}$ ). The major savings are obtained by use of compost as a substitute for peat in the production of growth media. However, it may be difficult for a specific composting plant to document how the compost is used and what it actually substitutes for. Two cases representing various technologies were assessed showing how GHGs accounting can be done when specific information and data are available.
\end{abstract}

Keywords: Composting, greenhouse gases, global warming, $\mathrm{CO}_{2}$ accounting, UOD tables 


\section{Introduction}

Composting is a common treatment of biodegradable waste. Approximately 2000 composting facilities for household organic wastes are in operation in Europe, $40 \%$ of which are only treating garden waste (ECN, 2008). Composting is a relatively simple, durable and inexpensive technology for stabilising and reducing biodegradable waste (Crowe et al., 2002). Composting could be an important technology in developing countries, where the waste usually has high content of wet organic materials. However, composting is also a suitable treatment option for biological waste in developed countries. For example, in the Netherlands, $97 \%$ of source separated biowaste is treated in composting facilities (Brinkmann et al., 2004). A range of technologies is in operation worldwide, from unmanaged static piles to highly engineered systems with automatic turning and treatment of the released gases in biofilters.

In a global warming (GW) context, composting contributes to emissions as well as to avoided emissions. Greenhouse gases (GHGs) are released from composting facilities due to degradation of organic matter and due to energy used by heavy machinery used for turning and managing of the waste. The finished product (compost) can be used on land. The benefit is twofold: the use of inorganic fertilizers is avoided and carbon is bound to soil. Compost can also replace peat in the production of growth media and thus avoid the emissions occurring during peat extraction and subsequent mineralization under aerobic conditions (Boldrin et al., 2009b).

The purpose of this paper is to describe composting of waste from a GW perspective and provide information about processes and data useful in accounting GHG emissions. The GHGs accounting is done as suggested by Gentil et al. (2009) distinguishing between Upstream, Operation and Downstream (UOD) contributions and between fossil and biogenic carbon dioxide $\left(\mathrm{CO}_{2}\right)$. A schematic representation of the assessed system and the alternative options for use of compost is presented in Figure 1.

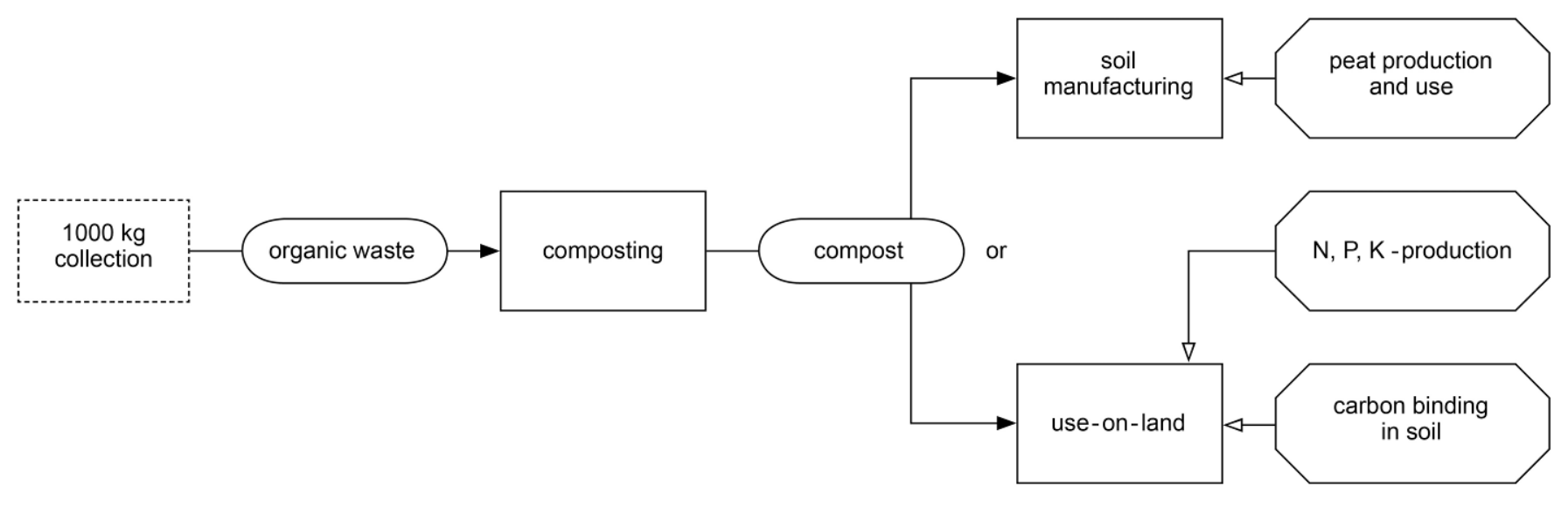

Figure 1 - Schematic representation of the assessed system.

According to the Kyoto protocol, GHG emissions should be reported annually on a national basis. The 2006 IPCC Guidelines for National Greenhouse Gas Inventories (Eggleston et al., 2006) provides detailed guidelines on how to estimate the annual GHG emissions from biological treatment of waste. Default values have been reported for GHG emissions from biological treatment of waste with no further specification of technology and waste type. This paper will summarize estimated emissions from composting and provide likely ranges for both direct and indirect emissions. Such contributions are in this study called Global Warming Factors (GWFs) and are normalized to $\mathrm{CO}_{2}$-equivalents (eq.) tonne ${ }^{-1}$ wet waste (ww). Estimated GWFs can be used for different GHG emission reporting mechanisms, having different scopes and boundaries, as described in Gentil et al. (2009). Three different technologies have 
been assessed (open, enclosed and home composting) and two cases have been presented with detailed information on all contributions of GHG emissions. Composting in developing countries is unfortunately not completely covered, because despite composting is widely practiced in such countries, data availability on process inventories is still very scarce. For instance, recently Liamsanguan \& Gheewala (2008) and Zhao et al. (2009) performed two LCA studies on municipal solid waste management in Thailand and China: in both cases inventory data regarding composting were taken from literature and/or databases because of lack of specific data.

\section{Overview of solid waste composting technologies}

The following paragraphs provide a general description of the key characteristics of the principal organic waste composting technologies. The main focus is on the issues that are considered important with respect to $\mathrm{GW}$ and $\mathrm{GHGs}$ accounting.

The composition and characteristics of the feedstock are very important for both designing and operating the composting plant and for the final quality of the compost (Haug, 1993). GHG emissions from the plant will also depend on the various types of machinery used in open or closed facilities, the turning rates, types of emission controls, and the internal temperature/moisture conditions. Theoretically, any kind of biodegradable waste can be composted. Practically, only a few waste fractions are composted in relevant amounts. Composting systems are also based on a broad spectrum of technologies, with individual technologies customized to specific waste fractions.

Table 1 presents the organic waste fractions and the technologies covered by this study. In this table, we try to define the level of relevance of a technology with respect to a waste fraction. This study focuses on Municipal Solid Waste (MSW), but the results could eventually apply to other waste fractions having similar characteristics. For the sake of simplicity, we have aggregated different organic waste fractions in two main fractions, defined as:

- Food waste: source separated food and organic fractions of market wastes.

- Garden and park waste: coming from private gardens and public parks. It consists of grass from lawn mowing, hedge cuttings, prunings, and leaves; from a process perspective, other materials with similar composition may be assimilated, e.g. crop residues, bark and forestry waste. Also paper, mostly made of cellulose, shows similar behavioural patterns

Table 1 - Composting technologies and waste fractions that are covered in this study. The crosses indicate which waste fractions the technologies are most widely used for.

\begin{tabular}{llcc}
\hline \multicolumn{2}{c}{ Technology } & Food waste & Garden waste \\
\hline Open technologies & Windrow & $\mathrm{X}$ & $\mathrm{X}$ \\
& Static pile & $\mathrm{X}$ & $\mathrm{X}$ \\
& Mat & & $\mathrm{X}$ \\
& Vermicomposting & $\mathrm{X}$ & \\
\hline Enclosed technologies & Channel and cell & $\mathrm{X}$ & $\mathrm{X}$ \\
& Aerated pile & $\mathrm{X}$ & \\
& Brikollari & $\mathrm{X}$ & $\mathrm{X}$ \\
\hline Reactor technologies & Tunnel reactor & $\mathrm{X}$ & \\
& Box and container & $\mathrm{X}$ & \\
& Rotating drum & $\mathrm{X}$ & $\mathrm{X}$ \\
& Tower & $\mathrm{X}$ & \\
\hline Other & Home composting & $\mathrm{X}$ & \\
\hline
\end{tabular}


In many countries, household food waste and garden waste are collected together in a fraction called "VFG" (Vegetable, Fruit, Garden) or "biowaste" which can be composted. In many cases, food waste and garden waste are mixed on purpose at the composting plant, so that garden waste provides structure to the feedstock. In this study, the two fractions will be kept separated. Allocation of emissions could be carried out according to the ratio of food and garden waste in the composting feedstock.

Different approaches have been used to classify composting technologies. The most common distinction is whether the degradation takes place outdoor, in enclosed buildings or in private gardens (home composting or backyard composting as it is also called).

\subsection{Open technologies}

In open technologies composting is performed in outdoor facilities. The gaseous emissions are in general neither collected nor treated, but released to the atmosphere. Open technologies are in general simpler and less engineered than enclosed technologies.

\section{Windrow and mat composting}

In windrow composting, waste is placed in triangular or trapezoidal windrows. Ventilation could be natural (diffusion and convection) or active (forced or vacuum-induced aeration). Turning of the windrows is often necessary and in most cases performed with a turning machine or a front loader. Turning results in increased porosity and homogenization of compost in terms of moisture and ensures that all compost is exposed to high temperature. The frequency of turning may influence the composting time, especially of those materials with tendency to clog. The size and shape of the windrows are determined by the turning equipment and the type of aeration. Mat composting is a variation of windrow composting, where layers of feedstock with different characteristics are laid on top of each other and the bulky materials are placed at the bottom to facilitate bottom-up convective ventilation.

\section{Static pile composting}

Static piles have the shape of a truncated pyramid and are not agitated nor turned. Ventilation is assured by sufficient material porosity, which could be reached by using bulking agents. In alternative, active ventilation is also possible by placing aeration pipes or blowers directly in the piles or at their base.

\subsection{Enclosed technologies}

In enclosed systems, the composting process takes place in an enclosed building. This facilitates the possibility of controlling the exhaust gases and a common treatment is filtration of the air in biofilters. In most of the enclosed technologies (including reactor technologies) the retention time is limited which means that curing of the material in open windrows or piles is often required afterwards.

\section{Channel and cell composting}

In channel composting, the raw material is placed in enclosed windrows which are individually controlled. The channels are separated by walls, which usually also are used as tracks for the turning machines. If the channels are short they are called cells. The compost material is moved from one end to the other (or from one channel to the next) during the process and it is actively aerated and turned with various frequencies (e.g. every day or every other day). 
Aerated pile

Aerated pile composting is similar to the open windrow technology. The difference is that aerated pile composting takes place in an enclosed building and that turning is done with automated turning machines. An aeration system is normally installed underneath the piles to ensure a proper flow of oxygen. The difference between the channel and cell technology and the aerated pile technology is that the aerated pile is not placed in channels which can be individually controlled.

\subsection{Reactor technologies}

Reactor technologies (also called in-vessel systems) are a variant of enclosed technologies and they are assessed together with the enclosed technologies in this paper. Due to a smaller head space above the compost, the volume of exhaust gases that needs to be treated in a reactor is smaller. There is better control of the exhaust gases compared to enclosed technologies and a biofilter is almost always installed.

\section{Tunnel composting}

Tunnel reactors are used for composting organic MSW, sewage sludge and manure. Generally there is good process control and the exhaust gases are controlled and recirculated to prevent atmospheric emissions and increase homogenization of internal conditions (e.g. temperature and moisture). Some systems are static and some are agitated and the level of process control also varies significantly.

\section{Rotating drum composting}

Rotating drum composting is a reactor technology that is primarily used for organic MSW. As the name indicates, this composting technology ensures constant movement (rotation) of the material and concurrent aeration, which results in a very quick breakdown of organic materials in MSW, after which (retention time from 1-10 days) they easily can be separated from non-compostable materials and sent to the next process/curing stage. One of the drawbacks of this technology is the relatively large electricity requirements for the rotation.

\subsection{Home composting}

In home composting (also called backyard composting) handling of waste is undertaken at a private level. Because the composting is performed with minimal equipment (plastic composters, wooden boxes, homemade enclosures using fencing) and very different levels of control, an average home composting process can hardly be defined. One main advantage of home composting is that no external energy is required for transport or processing. The key point from a GW perspective is to ensure proper "blending" of different materials and to ensure that the heap is sufficiently bulky and aerated, which avoids significant production/release of methane $\left(\mathrm{CH}_{4}\right)$.

\section{Composting technologies, GHG emissions and GWFs}

The GHG emissions are defined in terms of:

- Direct emissions, directly linked to activities at the composting site and the degradation of the waste.

- Indirect emissions or avoided emissions taking place outside the composting site. These are:

- Upstream activities such as production of materials and electricity used at the site, the provision of fuels used on the site and the construction of the facilities. 
- Downstream activities such as avoided emissions when substituting peat or fertilizer or binding of carbon in the soil when compost is applied on land.

GHG emissions are reported according to the technology type and the waste type. Emission factors (EFs) for electricity provision, fuel provision and fuel combustion are taken from Fruergaard et al. (2009) and presented in Table 2. The emission factor for electricity is very dependent on the fuel mix used and whether or not there is co-generation (use of heat), thus it varies a lot from country-to-country as well as from technology-to-technology. The range we have used in our estimations is based on low and high averages for the Nordic countries and Central Europe (Fruergaard et al., 2009).

Table 2 - Emission factors (EFs) relevant in GHG accounting for composting.

\begin{tabular}{|c|c|c|}
\hline Type of process/emission & Emission factor & Reference \\
\hline Provision of diesel oil & $0.4-0.5 \mathrm{~kg} \mathrm{CO}_{2}$-eq litre ${ }^{-1}$ diesel & Fruergaard et al. (2009) \\
\hline Combustion of diesel oil & $2.7 \mathrm{~kg} \mathrm{CO}_{2}$-eq litre ${ }^{-1}$ diesel & Fruergaard et al. (2009) \\
\hline Provision of electricity & $0.1-0.9 \mathrm{~kg} \mathrm{CO}_{2}$-eq kWh $\mathrm{kW}^{-1}$ & Fruergaard et al. (2009) \\
\hline Production of $\mathbf{N}$ fertilizer & 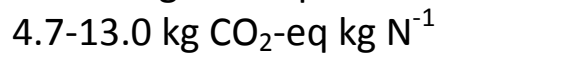 & Table 10 \\
\hline Production of $\mathbf{P}$ fertilizer & $0.5-3.1 \mathrm{~kg} \mathrm{CO}_{2}$-eq kg P-1 & Table 10 \\
\hline Production of $\mathrm{K}$ fertilizer & $0.4-1.5 \mathrm{~kg} \mathrm{CO}_{2}$-eq kg K ${ }^{-1}$ & Table 10 \\
\hline Production of peat & $550-1197 \mathrm{~kg} \mathrm{CO}_{2}$-eq tonne ${ }^{-1}$ peat & Section 3.3 \\
\hline
\end{tabular}

\subsection{Indirect upstream emissions}

The upstream contributions to GW are for the composting system related to:

- Provision of fuels: production and transport of fuels are assumed to be $0.4-0.5 \mathrm{~kg} \mathrm{CO}_{2}$ litre $^{-1}$ diesel (Fruergaard et al., 2009).

- Variable use of electricity for lighting on the site, administration buildings, and electrical equipment for the treatment of waste. The amount of electricity use can vary a lot, depending on the composting technology under consideration. In general, open technologies use less electricity than closed technologies. Typical values for open technologies are in the range of 0.023-19.7 kWh tonne $\mathrm{k}^{-1}$ of ww (Finnveden et al., 2000; Recycled Organics Unit, 2003; Komilis \& Ham, 2004; EC, 2006; Fisher, 2006; Boldrin et al., 2009a; Cabaraban et al., 2008), but values are mostly in the lower part of the range. The electricity use for managing a reactor composting plant is in the range of 9-65 kWh tonne ${ }^{-1}$ ww (Smith et al., 2001; Baky \& Eriksson, 2003; NIRAS, 2004; Brinkmann et al., 2004; EC, 2006; Fisher, 2006; Güereca et al., 2006; Cabaraban et al., 2008; EASEWASTE database), while Komilis \& Ham (2004) report 16.1-16.9 kWh tonne ${ }^{-1}$ ww of electricity used for facilities where windrows are placed on an enclosed composting pad. GHG emissions from the use of electricity can be calculated using emission factors reported in Table 2.

- Provision of other materials used at the composting site (e.g. oil, detergents, lubricants, etc). Very little data is available in literature and therefore no data are included in this paper.

\subsection{Direct emissions}

Direct emissions from composting can be divided into two main categories: emissions from fuel combustion and gaseous emissions occurring in different phases of waste treatment due to degradation/mineralization of the organic material. In the next paragraphs, the release of the following compounds is described and estimated: fossil $\mathrm{CO}_{2}$, biogenic $\mathrm{CO}_{2}, \mathrm{CH}_{4}$ and nitrous oxide $\left(\mathrm{N}_{2} \mathrm{O}\right)$.

Direct $\mathrm{CO}_{2}$ emissions from fossil fuel combustion are mainly from shredders, front loaders and turning equipment. Fuel consumption is generally larger in open technologies than in enclosed 
technologies. Typical values for diesel consumption in open technologies are in the range 0.4-6.0 litre diesel tonne ${ }^{-1}$ ww (Smith et al., 2001; USEPA, 2006; Recycled Organics Unit, 2003; Komilis \& Ham, 2004; EC, 2006; Fisher, 2006; Boldrin, 2007; Kranert \& Gottschall, 2007; Boldrin et al., 2009a), but in most cases a consumption around 3 litres tonne ${ }^{-1} \mathrm{ww}$ is reported. For enclosed technologies diesel consumption is reported being 0.13-3.0 litre tonne ${ }^{-1}$ ww (Komilis \& Ham, 2004; EC, 2006; Fisher, 2006), but typically in the lower end of the range. GHG emissions from fuel combustion can be calculated using emission factors reported in Table 2. The combustion of fuels from collection and transportation of waste and compost is not included here, since this issue is covered in Eisted et al. (2009). Avoided collection and transportation of waste is one of the main benefits in terms of GHG emissions of home composting, as also assessed in Fisher (2006).

The main gaseous emission from composting is biogenic $\mathrm{CO}_{2}$ which, in national inventories, is accounted for as part of the natural carbon cycle with land-use change and forestry estimates; thus it is not counted as a waste sector emission (Eggleston et al., 2006). The main GHGs that contribute to global warming are $\mathrm{CH}_{4}$ and $\mathrm{N}_{2} \mathrm{O}$. The release of these gases depends on the technology, the waste input and above all the management of the process. A properly blended starting mix will avoid incurring additional losses of $\mathrm{N}$, whilst properly designed and managed forced aeration and a timely turning (when needed) will avoid triggering production and subsequent release of $\mathrm{CH}_{4}$. The differences in carbon (C) and nitrogen $(\mathrm{N})$ contents in the different waste fractions are presented in Table 3.

Table 3 - Typical carbon and nitrogen contents of the different waste types considered.

\begin{tabular}{|c|c|c|c|c|c|}
\hline Compound & Unit & Food waste & Reference & Garden waste & Reference \\
\hline \multirow[t]{2}{*}{ Carbon (C) } & kg tonne $^{-1} w w$ & $100-365$ & $3,4,5$ & $93-250$ & $2,3,4$ \\
\hline & $\mathrm{kg}_{\text {tonne }} \mathrm{e}^{-1} \mathrm{dm}$ & $249-491$ & $1,3,4,5,6$ & $150-460$ & $1,2,3,4$ \\
\hline \multirow[t]{2}{*}{ Nitrogen $(\mathrm{N})$ total } & kg tonne $e^{-1} w w$ & $3.7-13$ & $3,4,5$ & $2.3-17$ & $2,3,4$ \\
\hline & kg tonne $e^{-1} \mathrm{dm}$ & $10-26$ & $3,4,5,6$ & $17-75$ & $2,3,4$ \\
\hline 1. Ham \& Komilis (2003) & 3. Tcho & noglous (1993) & & Eklind et al. (1 & \\
\hline 2. Boldrin et al. (2009a) & 4. Willi & s (2005) & & 6. Hansen et al. & 007) \\
\hline
\end{tabular}

Some facilities (enclosed technologies) might be equipped with odour removal devices. A common and inexpensive treatment is filtration of exhausts in biofilters. The efficiencies of biofilters depend on air flow, load, residence time, materials and design (Powelson et al., 2006; Chung, 2007). For facilities with biofilters, the removal efficiencies ( $\eta$ ) for $\mathrm{CH}_{4}$ are reported to be between 47-100 \% (Dalemo et al., 1997; Baky \& Eriksson, 2003; Powelson et al., 2006). More controversial data are found regarding $\mathrm{N}_{2} \mathrm{O}$ : $90 \%$ removal is reported by Dalemo et al. (1997) and Baky \& Eriksson (2003), while both Clemens \& Cuhls (2003) and Amlinger et al. (2008) report that biofilters could be a source of $\mathrm{N}_{2} \mathrm{O}$, especially when ammonia $\left(\mathrm{NH}_{3}\right)$ loads are high. If the technology does not include a biofilter (for example open technologies), the $\eta$ is set to zero in equation (3) and (4).

The amounts of carbon ( $\mathrm{C}_{\text {release, }} \mathrm{kg}$ ) and nitrogen $\left(\mathrm{N}_{\text {release, }} \mathrm{kg}\right)$ that are emitted to the atmosphere during composting can be calculated from the inputs of carbon $\left(\mathrm{C}_{\text {input }}, \mathrm{kg}\right)$ and nitrogen $\left(\mathrm{N}_{\text {input, }} \mathrm{kg}\right)$ and the fractional loss of the elements $\left(\mathrm{C}_{\text {loss } \%}\right)$ and $\left(\mathrm{N}_{\text {loss } \%}\right)$ :

$$
\begin{array}{ll}
C_{\text {release }}=C_{\text {input }} \times C_{\text {loss } \%} & \text { (Equation 1) } \\
N_{\text {release }}=N_{\text {input }} \times N_{\text {loss } \%} & \text { (Equation 2) }
\end{array}
$$


The total mass of $\mathrm{C}$ or $\mathrm{N}$ lost during composting (as \% of input mass) can be measured at composting facilities or found in literature and then used in equation (1) and (2) to calculate emissions. Alternatively, emissions could be estimated via a mass balance, calculating the difference between contents in input and output from the composting process. The latter approach is, however, very uncertain.

Several studies have investigated or reported degradation of organic matter and $\mathrm{C}$ during composting (Table 4). Production of mature compost requires degradation of $40-83 \%$ of the carbon contained in the compost. Most of this carbon is emitted as biogenic $\mathrm{CO}_{2}$, relatively small percentages are emitted as $\mathrm{CH}_{4}$, as explained later. If biofilters are present, part of such $\mathrm{CH}_{4}$ could be oxidized and additional biogenic $\mathrm{CO}_{2}$ is generated. An overview of $\mathrm{CO}_{2}$ emissions from composting of organic matter is presented in Table 5.

Table 4 - Organic matter and carbon degradation during composting as reported in literature.

\begin{tabular}{lccc}
\hline Substance & Degradation (\%) & Reference & Comment \\
\hline Carbon & $50-70$ & Dalemo et al. (1997) & Waste type not specified \\
Carbon & 83 & Hellebrand (1998) & Garden waste \\
Carbon & 68 & Smith et al. (2001) & Waste type not specified \\
Carbon & $40-60$ & Crowe et al. (2002) & Waste type not specified \\
Carbon & $62-66$ & Ham \& Komilis (2003) & Garden waste \\
Carbon & $66-70$ & Ham \& Komilis (2003) & Food waste \\
Carbon & 50 & Fisher (2006) & Both windrow and in-vessel \\
Carbon & 64 & Boldrin (2007) & Garden waste \\
Carbon & 56 & Andersen et al. (2009) & Garden waste \\
Organic matter & 50 & Edelmann et al. (2000) & 60\% kitchen waste, 40\% garden \\
& & & waste \\
Organic matter & 75 & Cabaraban et al. 2008) & Waste type not specified \\
\hline
\end{tabular}

Table 5 - $\mathrm{CO}_{2}$-biogenic emissions from degradation of organic matter during composting.

\begin{tabular}{lccc}
\hline Technology & Waste type & $\mathbf{C O}_{\mathbf{2}}$ emission (kg tonne $\mathbf{~}^{-1} \mathbf{~ w w )}$ & Reference \\
\hline Open & Garden & $118-413$ & $1,2,3$ \\
& Biowaste & $43-173$ & $1,4,5$ \\
Closed & Biowaste & $250-390$ & 2 \\
Home composting & Biowaste & $139-215$ & 1 \\
Not specified & Not specified & $98-563^{*}$ & 6 \\
\hline 1. Amlinger et al. (2008) & 4. Gronauer et al. (1997) & " not used in the \\
2. Komilis \& Ham (2004) & 5. Baky \& Eriksson (2003) & UOD tables \\
3. Andersen et al. (2009) & 6. EC (2006) & \\
\hline
\end{tabular}

The gaseous $\mathrm{N}$ losses during composting could be quite variable, depending on specific conditions of the process, such as the $\mathrm{C} / \mathrm{N}$ ratio and the nature of $\mathrm{N}$ in the feedstock (influencing availability of $\mathrm{N}$ ) as well as temperature, $\mathrm{pH}$ and aeration rate (determining $\mathrm{NH}_{3}$ evaporation). For instance, losses in the range $26-51 \%$ of the initial $\mathrm{N}$ content are reported for biowaste (Beck-Friis et al., 2000; NIRAS, 2004), while only $1.7 \%$ of initial $N$ is emitted in gaseous form in case of garden waste (Hellebrand, 1998). Finnveden et al. (2000) estimate a leakage of nitrogen to $7.5 \%$ of the initial $\mathrm{N}$ for a composting plant working in negative pressure. 
Methane $\left(\mathrm{CH}_{4}\right)$ is formed in anaerobic pockets of the compost material. The total loss of $\mathrm{CH}_{4}$ $\left(\mathrm{CH}_{4 \text {,release, }} \mathrm{kg}\right)$ is estimated from the total loss of carbon $\left(\mathrm{C}_{\text {release, }} \mathrm{kg}\right)$, the percentage of carbon that is lost as $\mathrm{CH}_{4}\left(\mathrm{CH}_{4}\right.$, emitted $)$ and the efficiency of the biofilter ( $\left.\eta\right)$.

$$
\mathrm{CH}_{4, \text { release }}=\mathrm{C}_{\text {release }} \times \mathrm{CH}_{4, \text { emitted }} \times(1-\eta) \times \frac{16}{12} \quad \text { (Equation 3) }
$$

Edelmann et al. (2000) reports 5.1-13.5\% of the degraded $\mathrm{C}$ emitted as $\mathrm{CH}_{4}$ depending on the management of the composting process. Lower values are found in other studies, as presented in Table 6, where quantification of emissions is also attempted. It is worth noting that Smith et al. (2001), USEPA (2006), Recycled Organics Unit, 2003 and Cabaraban et al. (2008) assume that no $\mathrm{CH}_{4}$ emissions occur during composting, despite Clemens \& Cuhls (2003) reports that $\mathrm{CH}_{4}$ emissions occur even in well aerated processes. Home composting is not well covered by literature, but Smith et al. (2001) assumes no $\mathrm{CH}_{4}$ is emitted. Whilst it is reasonable to assume that a certain release of $\mathrm{CH}_{4}$ does actually occur, optimisation of processes at compost sites is supposed to minimize the emissions, relative to figures reported in older studies. Hence adoption of lowest values for BAT technologies and process management seems reasonable for modern facilities.

Table 6 - CH4 emissions during composting of organic waste.

\begin{tabular}{|c|c|c|c|c|c|}
\hline Technology & Waste & $\begin{array}{c}\mathrm{CH}_{4}-\mathrm{C} \\
\text { (\% degraded C) }\end{array}$ & Reference & $\begin{array}{c}\mathrm{CH}_{4} \text { emission } \\
\left(\mathrm{kg}^{-1} \text { tonne }{ }^{-1} \text { ww) }\right.\end{array}$ & Reference \\
\hline \multirow[t]{2}{*}{ Open } & Garden & $2.1-2.7$ & $1,2,3$ & $0.05-6.8$ & $1,3,4$ \\
\hline & Biowaste & $0.8-2.5$ & 4 & $0.03-1.5$ & $4,7,8,9$ \\
\hline Enclosed & Biowaste & $2.4-3$ & 5,6 & $0.02-1.8$ & $4,5,7,8,9$ \\
\hline Home composting & Biowaste & $2.0-3.6$ & 4 & $0.8-2.2$ & 4 \\
\hline Not specified & Not spec. & & & $0.03-8^{*}$ & 10,11 \\
\hline \multicolumn{2}{|l|}{ 1. Hellebrand (1998) } & \multicolumn{2}{|c|}{ 5. Gronauer et al. (1997) } & \multicolumn{2}{|c|}{ 9. Brinkmann et al. (2004) } \\
\hline \multicolumn{2}{|c|}{ 2. Bjarnadottir et al. (2002) } & \multicolumn{2}{|c|}{ Marb et al. (1997) } & \multicolumn{2}{|c|}{ 10. Eggleston et al. (2006) } \\
\hline \multicolumn{2}{|c|}{ 3. Andersen et al. (2009) } & \multicolumn{2}{|c|}{ Baky \& Eriksson (2003) } & \multicolumn{2}{|l|}{ 11. EC (2006) } \\
\hline \multicolumn{2}{|c|}{ 4. Amlinger et al. (2008) } & \multicolumn{2}{|l|}{ Fisher (2006) } & \multicolumn{2}{|c|}{${ }^{*}$ not used in the UOD tables } \\
\hline
\end{tabular}

Nitrous Oxide $\left(\mathrm{N}_{2} \mathrm{O}\right)$ is primarily formed in anaerobic pockets where an oxygen gradient occurs (Beck-Friis et al., 2000) as a by-product of both nitrification and denitrification (Eggleston et al., 2006). Nitrous Oxide is mainly produced in the later stage of the composting process, when the readily available $\mathrm{C}$ has been consumed (He et al., 2000). The release of $\mathrm{N}_{2} \mathrm{O}\left(\mathrm{N}_{2} \mathrm{O}_{\text {release, }} \mathrm{kg}\right.$ ) can be calculated in the same way as $\mathrm{CH}_{4}$, where $\mathrm{N}_{2} \mathrm{O}_{\text {emitted }}$ is the fraction of input nitrogen lost as $\mathrm{N}_{2} \mathrm{O}$ during the composting process:

$$
N_{2} O_{\text {release }}=N_{\text {release }} \times N_{2} O_{\text {emitted }} \times(1-\eta) \times \frac{44}{28} \quad \text { (Equation 4) }
$$

In literature $\mathrm{N}_{2} \mathrm{O}$ emissions are reported on a total $\mathrm{N}$ basis or degraded $\mathrm{N}$ basis. Some examples are reported in Table 7. In other studies, $\mathrm{N}_{2} \mathrm{O}$ is not included in the accounting of GHG emissions (Smith et al., 2001; Recycled Organics Unit, 2003). Any other $\mathrm{GHGs}$ than $\mathrm{CO}_{2}, \mathrm{CH}_{4}$ and $\mathrm{N}_{2} \mathrm{O}$ are very unlikely to occur at compost sites, hence are not covered in this paper. 
Table 7 - N2O emissions during composting of organic waste.

\begin{tabular}{|c|c|c|c|c|c|c|}
\hline Technology & Waste & $\begin{array}{c}\mathrm{N}_{2} \mathrm{O}-\mathrm{N} \\
\text { (\% input N) }\end{array}$ & $\begin{array}{c}\mathrm{N}_{2} \mathrm{O}-\mathrm{N} \\
\text { (\% degraded } \mathrm{N} \text { ) }\end{array}$ & Reference & $\begin{array}{l}\mathrm{N}_{2} \mathrm{O} \text { emission } \\
\left(\mathrm{g} \text { tonne } \mathrm{e}^{-1} \mathrm{ww}\right)\end{array}$ & Reference \\
\hline \multirow[t]{2}{*}{ Open } & Garden & $0.5-1.8$ & $0.8-23$ & $1,2,3$ & $25-178$ & $2,3,4,5$ \\
\hline & Biowaste & $0.1-0.7$ & $2-17$ & $4,5,6$ & $7.5-252$ & $4,7,8,9$ \\
\hline Enclosed & Biowaste & 1.8 & & 10 & $10-120$ & $4,9,10,11$ \\
\hline Home composting & Biowaste & $0.95-1.25$ & $14-15$ & 4 & $192-454$ & 4 \\
\hline \multirow{2}{*}{\multicolumn{2}{|c|}{ Not spec. $\quad$ Not spe }} & & & & $10-600^{*}$ & $12,13,14$ \\
\hline \multirow{2}{*}{\multicolumn{2}{|c|}{$\begin{array}{ll}\text { 1. } & \text { Ballestero \& Douglas (1996) } \\
\text { 2. } & \text { Hellebrand (1998) }\end{array}$}} & \multicolumn{2}{|c|}{ 6. Dalemo et al. (1997) } & \multicolumn{3}{|c|}{ 11. Brinkmann et al. (2004) } \\
\hline & & 7. Bjarnadot & r et al. (2002) & 12. Egglesto & et al. (2006) & \\
\hline \multicolumn{2}{|c|}{ 3. Andersen et al. (2009) } & \multicolumn{2}{|c|}{ 8. Baky \& Eriksson (2003) } & \multicolumn{3}{|c|}{ 13. EC (2006) } \\
\hline \multicolumn{2}{|c|}{ 4. Amlinger et al. (2008) } & \multicolumn{2}{|c|}{ 9. Fisher (2006) } & \multicolumn{3}{|c|}{ 14. UNFCCC (2006) } \\
\hline \multicolumn{2}{|c|}{ 5. Finnveden et al. (2000) } & \multicolumn{2}{|c|}{ 10. Gronauer et al. (1997) } & \multicolumn{3}{|c|}{ " not used in the UOD tables } \\
\hline
\end{tabular}

\subsection{Indirect downstream emissions}

In this paper we consider GHG emissions only for two possible alternative uses of the compost produced from treatment of organic waste:

- Compost used in growth media in substitution of peat;

- Compost used on land as a soil amendment.

Downstream inventory does not include incineration of screened residues, landfilling of screened residues and/or compost, or the use of compost in landscaping works and/or in landfill topcovers. Estimation regarding incineration and landfilling could be done according to Astrup et al. (2009) and Manfredi et al. (2009).

\section{Use on land of compost}

Compost materials contain organic matter, which can be characterized as readily degradable, slowly degradable and stable organic matter. When degradable organic matter is oxidized, $\mathrm{CO}_{2}$ is emitted to the atmosphere. The stable organic matter has a turnover of 100 to 1000 years and thus a fraction of the $C$ is bound in soil for long periods (Smith et al., 2001; Favoino \& Hogg, 2008) and removed from the $\mathrm{C}$ cycle. This bound $\mathrm{C}$ can be seen as a sink of $\mathrm{CO}_{2}$ (as if it is removed from the atmosphere) and it can be credited as an avoided downstream emission of $\mathrm{CO}_{2}$ to the waste management system (Marmo, 2008). If $C_{\text {input }}(\mathrm{kg})$ is the $C$ content in compost and $C_{\text {bind }}$ is the fraction of $C$ which is "stable", then the sink of $\mathrm{CO}_{2}\left(\mathrm{CO}_{2, \text { bind }} ; \mathrm{kg}\right)$ can be calculated as:

$$
C O_{2, \text { bind }}=C_{\text {input }} \times C_{\text {bind }} \times \frac{44}{12} \quad \text { (Equation 5) }
$$

The $C$ still bound to soil after 100 years is estimated to be $2-10 \%$ of the input in compost (Smith et al., 2001; Brinkmann et al., 2004; Fisher, 2006), while Bruun et al. (2006) estimated 9-14 \% depending on the soil type and the crop rotation.

The $C$ content in compost is in the order $56-386 \mathrm{~kg}$ tonne $\mathrm{e}^{-1} \mathrm{ww}$ (Table 8), which means that 1-54 $\mathrm{kg} \mathrm{C}$ tonne ${ }^{-1}$ ww could be bound in soil, equivalent to $4-198 \mathrm{~kg} \mathrm{CO}_{2}$-eq tonne ${ }^{-1}$ compost. Carbon binding is thus in the order of 2-79 $\mathrm{kg} \mathrm{CO}_{2}$-eq tonne ${ }^{-1}$ of food waste and 3-73 $\mathrm{kg} \mathrm{CO}_{2}$-eq tonne $\mathrm{Cf}^{-1}$ garden waste, assuming mass losses during the composting process of $60 \%$ and $30 \%$ respectively. This estimation is somewhat lower than that provided by ICF (2005), which reports $270 \mathrm{~kg} \mathrm{CO}_{2}$-eq tonne ${ }^{-1} \mathrm{ww}$ is bound in soil, regardless of the type of waste and the composition of the compost. 
Table 8 - Typical carbon and nutrients (N, P, K) content of different compost types.

\begin{tabular}{|c|c|c|c|c|c|c|c|}
\hline \multirow[t]{2}{*}{ Compound } & \multirow[t]{2}{*}{ Unit } & \multicolumn{3}{|c|}{ From food waste } & \multicolumn{3}{|c|}{ From garden waste } \\
\hline & & & Value & Reference & & Value & Reference \\
\hline \multirow[t]{2}{*}{ Carbon (C) } & kg tonne ${ }^{-1} w w$ & & $63-386$ & 1 & & $56-202$ & 4 \\
\hline & kg tonne ${ }^{-1} \mathrm{dm}$ & & $191-470$ & $1,2,3,4$ & & $100-285$ & $1,2,4$ \\
\hline \multirow[t]{2}{*}{ Nitrogen $(\mathrm{N})$ total } & $\mathrm{kg}$ tonne ${ }^{-1} \mathrm{ww}$ & & $6.0-21.5$ & $1,4,5,6,7,8$ & & $3.9-8$ & 1,4 \\
\hline & $\mathrm{kg}$ tonne $\mathrm{e}^{-1} \mathrm{dm}$ & & $9-28$ & $\begin{array}{c}1,3,4,5,6,7 \\
9\end{array}$ & & $7.0-15.5$ & $1,4,9$ \\
\hline \multirow[t]{2}{*}{ Phosphorous (P) } & $\mathrm{kg}$ tonne ${ }^{-1} \mathrm{ww}$ & & $1.8-4.7$ & $1,4,5,6,7$ & & $1-4$ & 1,4 \\
\hline & $\mathrm{kg}_{\text {tonne }} \mathrm{e}^{-1} \mathrm{dm}$ & & $1.8-9.3$ & $1,3,4,5,6,7$ & & $1.5-7.3$ & 1,4 \\
\hline \multirow[t]{2}{*}{ Potassium (K) } & $\mathrm{kg}$ tonne ${ }^{-1} \mathrm{ww}$ & & $6.0-13.4$ & $1,4,7$ & & $5-13.8$ & 1,4 \\
\hline & kg tonne ${ }^{-1} \mathrm{dm}$ & & $3.4-23$ & $1,3,4,6,7$ & & $7.7-19.4$ & 1,4 \\
\hline \multicolumn{2}{|l|}{ 1. Ward et al. (2005) } & 4. & Boldrin et & 09b) & 7. & \multicolumn{2}{|c|}{ Schleiss (2007) } \\
\hline \multirow{2}{*}{\multicolumn{2}{|c|}{$\begin{array}{l}\text { 2. Ham \& Komilis (2003) } \\
\text { 3. Eklind et al. (1997) }\end{array}$}} & 5. & Brinkmann & (2004) & 8. & \multicolumn{2}{|c|}{ Finnveden et al. (2000) } \\
\hline & & 6. & Siebert (20 & & 9. & \multicolumn{2}{|c|}{ Hogg et al. (2002) } \\
\hline
\end{tabular}

Compost contains nutrients which can displace the use of mineral fertilizer produced by industrial processes (most often N, P, and $\mathrm{K}$ fertilizers). This assumes, however, that the compost is used rationally as part of a fertilization plan. Typical N, P, and $\mathrm{K}$ contents of food waste compost and garden waste compost are reported in Table 8.

The utilization efficiencies of the organic and mineral nutrients depend on different factors such as the mineralization rate after application, the type of soil and type of crop. The substitution ratios could thus vary between 0 and 1 . The amount of mineral fertilizers displaced (Mass disp $_{\text {) depends }}$

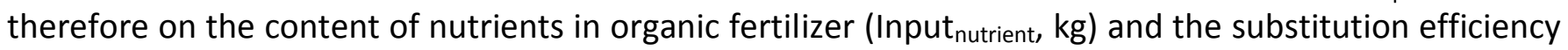
$\left(\right.$ Subs $\left._{\text {eff }}\right)$ and can be calculated as follow $(\mathrm{kg})$ :

$$
\text { Mass }_{\text {disp }}=\text { Input }_{\text {nutrient }} \times \text { Subs } s_{\text {eff }} \quad \text { (Equation 6) }
$$

Substitution ratios for N, P, and K are reported in literature (Dalemo et al., 1998; Vogt et al., 2002; Brinkmann et al., 2004; Hansen et al., 2006):

- $\quad \mathrm{N}: 20-60 \%$

- $P: 90-100 \%$

- $\mathrm{K}: 100 \%$

An estimation of the amount of mineral fertilizer replaced by the use of compost is done by combining substitution coefficients and N, P, and $\mathrm{K}$ contents reported in Table 8. Results are reported in Table 9. Similarly, Crowe et al. (2002) estimates that per tonne of ww 2.5-10 kg N, 0.5-1 kg P and 1-2 kg K can be recovered through composting.

Table 9 - Potential amount of inorganic fertilizers replaceable by use of compost.

\begin{tabular}{lccccc}
\hline Waste type & $\begin{array}{c}\text { Waste } \\
\text { input (kg) }\end{array}$ & $\begin{array}{c}\text { Compost } \\
\text { output } \mathbf{( k g )}\end{array}$ & \multicolumn{3}{c}{$\begin{array}{c}\text { Inorganic fertilizer replacement } \\
\text { (kg tonne }\end{array}$} \\
& & & $\mathbf{N}$ & treated waste) \\
P & K \\
\hline Food & 1000 & 400 & $0.5-5.2$ & $0.6-1.9$ & $2.4-5.4$ \\
Garden & 1000 & 700 & $0.5-3.4$ & $0.6-2.8$ & $3.5-9.7$ \\
\hline
\end{tabular}


The production of mineral fertilizer implies the use of energy and other materials resulting in emissions of GHG. GW contributions from production of commercial fertilizers are reported in literature and databases (see Table 10). Typical GHG emissions per $\mathrm{kg}$ of nutrients produced are 4.75-13.0 kg $\mathrm{CO}_{2^{-}}$ eq for $\mathrm{N}$ fertilizers, $0.52-3.09 \mathrm{~kg} \mathrm{CO}$-eq for $\mathrm{P}$ and $0.38-1.53 \mathrm{~kg} \mathrm{CO}_{2}$-eq for $\mathrm{K}$. The variability between different sources is at least partially due to the energy mix considered for electricity production. Combining such EFs (Table 2) with the amount of inorganic fertilizer replaced previously described, saved emissions can be estimated as: $4-81 \mathrm{~kg} \mathrm{CO}_{2}$ tonne ${ }^{-1}$ of food waste and 4-67 $\mathrm{kg} \mathrm{CO}_{2}$ tonne $\mathrm{C}^{-1}$ of garden waste.

Table 10 - GHG emissions for production of mineral fertilizers (kg CO2-eq kg-1 nutrient).

\begin{tabular}{cccc}
\hline $\mathbf{N}$ & $\mathbf{P}$ & $\mathbf{K}$ & Reference \\
\hline $11.5-13.0$ & $1.74-1.90$ & $0.69-0.79$ & Hansen et al. (2006) \\
8.65 & $1.28-2.72$ & $0.53-1.53$ & Ecoinvent \\
7.49 & 1.20 & 1.16 & GEMIS \\
5.29 & 0.52 & 0.38 & Smith et al. (2001) \\
$4.75-10.77$ & 3.095 & 0.56 & Audsley et al. (1997) \\
$5.34-9.56$ & $0.8-2.48$ & - & Wood \& Cowie (2004) \\
\hline
\end{tabular}

Application of treated organic waste to land (Use-On-Land, UOL) can result in emissions of $\mathrm{N}_{2} \mathrm{O}$. The amount of $\mathrm{N}_{2} \mathrm{O}$ emitted is proportional, among other things, to the amount of $\mathrm{N}$ applied with compost. If $\mathrm{N}_{\text {input }}$ is the content of nitrogen $(\mathrm{kg})$ per tonne of compost and $\mathrm{N}_{2} \mathrm{O}_{\% \mathrm{~N}}$ is the fraction of nitrogen converted to $\mathrm{N}_{2} \mathrm{O}$, then the release of $\mathrm{N}_{2} \mathrm{O}\left(\mathrm{N}_{2} \mathrm{O}_{\cup O L}, \mathrm{~kg}\right)$ to air per tonne of ww can be calculated as:

$$
N_{2} O_{U O L}=N_{\text {input }} \times N_{2} O_{\% N} \times \frac{44}{28} \quad \text { (Equation 7) }
$$

Different studies report that 1.0-2.2 \% of the nitrogen applied with compost is emitted as $\mathrm{N}_{2} \mathrm{O}$ (Dalemo et al., 1998; Vogt et al., 2002; Brinkmann et al., 2004; Bruun et al., 2006; Eggleston et al., 2006). Fisher (2006) assumes that no GHG is emitted after the spreading of compost.

Using composition data from Table 8 and assuming $60 \%$ mass loss for food waste and $30 \%$ for garden waste during the composting process, emissions of $\mathrm{N}_{2} \mathrm{O}$ after spreading of compost on land can be estimated to be 38-297 $\mathrm{g} \mathrm{N}_{2} \mathrm{O}$ tonne ${ }^{-1}$ of food waste and 43-194 $\mathrm{g} \mathrm{N}_{2} \mathrm{O}$ tonne ${ }^{-1}$ of garden waste.

The foregoing, basically refers to a possible release of $\mathrm{N}$ from organic fertilisers during periods in which vegetation is not able to take $\mathrm{N}$ in. Other authors, instead, have actually remarked the possibility of an overall reduction of $\mathrm{N}_{2} \mathrm{O}$ from farmlands where compost is used. This mostly refers to the possibility to replace a readily available source of $\mathrm{N}$ with a slow-release one, which avoids creation of an excessive $\mathrm{N}$ pool in the soil susceptible of forming $\mathrm{N}_{2} \mathrm{O}$. Favoino and Hogg (2008) have for instance derived a potential saved emission in the range of 20-201 g N $\mathrm{N}_{2} \mathrm{O}$ tonne $\mathrm{H}^{-1}$ of compost (assuming avoided $\mathrm{N}_{2} \mathrm{O}$ emission between $0.05 \%$ and $0.5 \%$ of the total $\mathrm{N}$ applied through mineral fertilisers), equivalent to 8-81 $\mathrm{g} \mathrm{N}_{2} \mathrm{O}$ tonne ${ }^{-1}$ of food waste and 14-141 $\mathrm{g} \mathrm{N}_{2} \mathrm{O}$ tonne $\mathrm{e}^{-1}$ of garden waste.

Spreading of compost on land involves some fuel consumption. Dalemo et al. (1997) reports that diesel consumption for spreading of solid residues is $444 \mathrm{MJ} \mathrm{ha}^{-1}$, i.e. 12 litre ha ${ }^{-1}$. If the EU Nitrate Directive is fulfilled (i.e. $170 \mathrm{~kg} \mathrm{~N} \mathrm{ha}^{-1}$, EEC (1991)), maximum allowed compost application would be 8- 
28 tonne ha $^{-1}$ for food waste and 21-44 tonne ha-1 for garden waste. Assuming the mass losses during compost as above, the spreading would result in 0.17-0.60 litre tonne ${ }^{-1}$ of food waste and 0.19-0.40 litre tonne ${ }^{-1}$ of garden waste. In the case of home composting, spreading is assumed to be done manually (no fuel consumption is reported).

The use of compost on land can have further benefits on GW for downstream effects of its application. Beside savings of inorganic fertilizers and carbon binding, spreading of compost on land can result in increased water retention of the soil (reduced irrigation), reduced herbicides/biocides requirements, improved soil structure, and reduced erosion. All these aspects could implicate some GHG savings, which are not quantified in this paper because of lack of data or of the high uncertainty related to that (i.e. local conditions, use, agricultural methods, etc...). However, it is worth noticing that some estimates allocate an important part of benefits for GW coming from application of compost, to these induced effects on soils.

\section{Peat substitution}

Compost produced from organic waste can be a potential alternative to peat in the production of growth media. Compost can dilute peat at different ratios, depending on the type of growth media, and up to $50 \%$ (Prasad \& Maher, 2006), although this typically refers to professional growth media, whereas media for amateur gardening may include up to $100 \%$ compost. The substitution is usually done on a $1: 1$ volume basis (Mathur \& Voisin, 1996), i.e. a certain volume of peat (e.g. $1 \mathrm{~m}^{3}$ ) is substituted by an equivalent volume of compost $\left(1 \mathrm{~m}^{3}\right)$. Avoiding use of peat saves $\mathrm{GHG}$ emissions occurring during the extraction, transportation and use (i.e. degradation) of peat materials. Different studies estimated GHG emissions within a 100 year period from all phases of the peat life cycle for some European countries: around $970 \mathrm{~kg} \mathrm{CO}$-eq are emitted per tonne of peat used in Denmark (Boldrin et al., 2009b), 621-1197 $\mathrm{kg} \mathrm{CO}_{2}$ tonne ${ }^{-1}$ of peat are emitted in the German scenario (Kranert \& Gottschall, 2007), while $550 \mathrm{~kg}$ $\mathrm{CO}_{2}$ tonne ${ }^{-1}$ of peat are estimated in a Dutch study (Brinkmann et al., 2004). Part of the variability could be explained with the origin of peat and related transportation distances. In Smith et al. (2001) it is estimated that $823 \mathrm{~kg} \mathrm{CO}_{2}$ are emitted per tonne of peat, without including land preparation, extraction and transportation in their calculations.

Considering different compost and peat densities, it is here assumed that 1 tonne of compost can replace the use of 0.2-1 tonne of peat. Avoided emissions are thus in the order of $110-1197 \mathrm{~kg} \mathrm{CO}_{2^{-}}$ eq tonne $\mathrm{i}^{-1}$ of compost used in growth media preparation instead of peat (44-479 $\mathrm{kg} \mathrm{CO}_{2}$-eq tonne $\mathrm{C}^{-1}$ of food waste and 77-838 $\mathrm{kg} \mathrm{CO}_{2}$-eq tonne ${ }^{-1}$ of garden waste). Such an estimate is much higher than the $16.2 \mathrm{~kg} \mathrm{CO}_{2}$-eq tonne ${ }^{-1}$ of compost reported by Barton et al. (2008). In addition, the use of compost in growth media preparation could also replace some mineral fertilizers otherwise added to the mix (Boldrin et al., 2009b). Such estimation is not included here, but it could be carried out in the same way described above for the use of compost on land.

Compost used in growth media is eventually degraded and the $\mathrm{C}$ contained is released to atmosphere as biogenic $\mathrm{CO}_{2}$. According to the $\mathrm{C}$ content in compost reported in Table 8, the emission of biogenic $\mathrm{CO}_{2}$ is estimated in the range $231-1415 \mathrm{~kg} \mathrm{CO}_{2}$ tonne ${ }^{-1}$ compost for food waste and $205-741 \mathrm{~kg}$ $\mathrm{CO}_{2}$ tonne ${ }^{-1}$ compost for garden waste. Considering the mass losses during the composting process, the emission is estimated to be $92-566 \mathrm{~kg} \mathrm{CO}_{2}$ tonne ${ }^{-1} \mathrm{ww}$ for food waste and $143-518 \mathrm{~kg} \mathrm{CO}_{2}$ tonne ${ }^{-1} \mathrm{ww}$ for garden waste. Emissions of $\mathrm{N}_{2} \mathrm{O}$ related to use of compost in growth media is not reported or mentioned anywhere. It is here assumed it is the same as for the use on land case: 38-297 g N2O tonne of food waste treated and 43-194 $\mathrm{g} \mathrm{N}_{2} \mathrm{O}$ tonne ${ }^{-1}$ of garden waste treated. 


\section{Results and discussion}

Results of GW contribution for the composting process are presented in Upstream, Operation and Downstream (UOD) tables for three overall technologies:

- Open technologies (mix of garden waste and food waste or solely garden waste) with no collection or treatment of the gases (Table 11).

- Enclosed technologies (food and garden waste) including both enclosed technologies and reactor technologies as defined above. In some cases a biofilter is used for exhaust treatment (Table 12).

- Home composting (mix of vegetable kitchen waste and some garden waste) (Table 13).

The contributions to global warming by biogenic $\mathrm{CO}_{2}$ are calculated according to the criteria set by Christensen et al. (2009), i.e. Global Warming Potential (GWP) $=0$. The GWP of $\mathrm{CO}_{2}$-fossil is 1 , the GWP for $\mathrm{CH}_{4}$ is 25 (1 kg of $\mathrm{CH}_{4}=25 \mathrm{~kg}$ of $\mathrm{CO}_{2}$ ) and 298 for $\mathrm{N}_{2} \mathrm{O}\left(1 \mathrm{~kg}\right.$ of $\mathrm{N}_{2} \mathrm{O}=298 \mathrm{~kg}$ of $\mathrm{CO}_{2}$ ) (Solomon et al., 2007).

The downstream emissions have been estimated allocating emissions according to the nutrient contents (e.g. high $\mathrm{N}$ content results in large mineral fertilizer savings but also higher $\mathrm{N}_{2} \mathrm{O}$ emissions).

The results show that energy issues (electricity and diesel) have a minor relevance in the GHG accounting of composting technologies. Moreover, if the electricity emission factor is low-medium then the GHG emissions related to use of electricity and fuel are quite similar for open and enclosed technologies. GHG emissions due to degradation of organic matter during the composting process (direct) seem to depend both on the management and on the type of technology. Proper blending of input feedstock, and optimised adoption of forced aeration may minimise the production of GHGs, whilst treatment for removal of $\mathrm{CH}_{4}$ and $\mathrm{N}_{2} \mathrm{O}$ could result in large improvements in the system compared to open systems where gaseous emissions are not treated.

Downstream emissions represent the crucial factor in GHG accounting for different composting systems. Use of compost for peat substitution has a large potential for emission savings and from a GW perspective it could be preferable to the use of compost on land. Among the different mineral fertilizer included in the evaluation, nitrogen is the one potentially leading to large savings.

When comparing different types of waste, the main conclusion is that garden waste has lower energy requirements and lower emissions than food waste, but also less potential benefits because of the lower content of nutrients.

Only a few studies regarding direct gaseous emissions from home composting are available. If such figures were confirmed, home composting would perform better than large facilities, both because of no energy requirements and avoided collection and transportation (the latter is not quantified here). Assumptions made on the use of home compost and what it substitutes for could introduce additional uncertainty. A more thorough survey is recommended.

Aggregated results presented in Table 11, Table 12 and Table 13 are in line with figures reported in other reports. Smith et al. (2001) reports net fluxes of GHGs: $-37 \mathrm{~kg} \mathrm{CO}_{2}$-eq tonne ${ }^{-1}$ ww for open composting, $-32 \mathrm{~kg} \mathrm{CO}_{2}$-eq tonne ${ }^{-1} \mathrm{ww}$ for enclosed composting and $-58 \mathrm{~kg} \mathrm{CO}_{2}$-eq tonne ${ }^{-1} \mathrm{ww}$ for home composting. Fisher (2006) reports GWFs in the order of $13 \mathrm{~kg} \mathrm{CO}_{2}$-eq tonne ${ }^{-1} \mathrm{ww}$ for windrow composting and $12 \mathrm{~kg} \mathrm{CO}_{2}$-eq tonne ${ }^{-1} \mathrm{ww}$ for in-vessel composting, while a factor of $-202 \mathrm{~kg} \mathrm{CO}_{2}$-eq tonne ${ }^{-1}$ ww was found in Chen \& Lin (2008). A common aspect of these studies is that they do not show the variability of emission factors. This is mainly because they make precise assumptions even when analysing complex and heterogeneous situations, such as a national waste management policy.

Two examples have been selected to better illustrate the use and interpretation of the UOD tables and to show how GWFs of composting can be calculated if data are available on the various contributing processes. The two cases are: reactor composting of biowaste and windrow composting of garden waste. 
Composting of household biowaste is extensively covered by a Dutch study (Brinkmann et al., 2004). In the Netherlands in 2004, $86 \%$ of the source separated biowaste was treated in enclosed system, while the remaining $14 \%$ was composted in open windrow systems. The average electricity consumption in Dutch facilities was $32 \mathrm{kWh}$ tonne $\mathrm{e}^{-1} \mathrm{wW}$ and $400 \mathrm{~kg}$ of compost were produced out of every tonne of separately collected biowaste. Gas emissions, after biofilter, were estimated to be $195 \mathrm{~g}$ $\mathrm{CH}_{4}$ tonne ${ }^{-1}$ of biowaste and $101 \mathrm{~g} \mathrm{~N}_{2} \mathrm{O}$ tonne ${ }^{-1}$ of biowaste. According to the emission factors reported in Table 2 the GWF of upstream activities is 3.2-28.8 $\mathrm{kg} \mathrm{CO}_{2}$-eq tonne ${ }^{-1} \mathrm{ww}$ and the GWF of direct emissions is $35 \mathrm{~kg} \mathrm{CO}_{2}$-eq tonne ${ }^{-1} \mathrm{Ww}$. The compost produced contained $9.4 \mathrm{~kg} \mathrm{~N}$ tonne ${ }^{-1}, 4.8 \mathrm{~kg} \mathrm{P}_{2} \mathrm{O}_{5}$ tonne $^{-1}$ (i.e. $2.1 \mathrm{~kg} \mathrm{P}$ tonne $^{-1}$ ) and $8.1 \mathrm{~kg} \mathrm{~K}_{2} \mathrm{O}$ tonne ${ }^{-1}$ (i.e. $6.7 \mathrm{~kg} \mathrm{~K}$ tonne $^{-1}$ ). The substitution ratios are assumed to be $60 \%$ for $\mathrm{N}, 90 \%$ for $\mathrm{P}$ and $100 \%$ for $\mathrm{K}$. Substitution of mineral fertilizers would save emissions in the order 30.3-89.5 $\mathrm{kg} \mathrm{CO}_{2}$-eq tonne ${ }^{-1}$ of compost (12.1-35.8 $\mathrm{kg} \mathrm{CO}_{2}$-eq tonne $\mathrm{ww}^{-1}$ as collected waste). $\mathrm{N}_{2} \mathrm{O}$ emissions from application of compost on land were assumed to be $1.25 \%$ of the applied nitrogen, which means $47 \mathrm{~g} \mathrm{~N}_{2} \mathrm{O}$ tonne ${ }^{-1} \mathrm{ww}$ (or $14 \mathrm{~kg} \mathrm{CO}_{2}$-eq tonne ${ }^{-1} \mathrm{ww}$ ). Carbon binding was reported to save $24.2 \mathrm{~kg} \mathrm{CO}_{2}$-eq tonne ${ }^{-1} \mathrm{ww}$. In modelling peat substitution, it was estimated that 1 tonne of compost could replace $830 \mathrm{~kg}$ of peat and $550 \mathrm{~kg} \mathrm{CO}_{2}$-eq tonne ${ }^{-1}$ were emitted during peat life cycle. Considering the mass loss, saving from peat substitution were thus in the order of $183 \mathrm{~kg} \mathrm{CO}_{2}$-eq tonne ${ }^{-1} \mathrm{ww}$. As for the use of compost on land, an emission of $47 \mathrm{~g} \mathrm{~N}_{2} \mathrm{O}$ tonne ${ }^{-1} \mathrm{ww}$ from compost degradation was also assumed here. The results are summarized in Table 14.

Another composting technology was covered extensively in a Danish study (Boldrin et al., 2009a). A facility in Aarhus (Denmark) treated garden waste in an open windrow system with no gas treatment. The mass loss during composting was $28 \%$. The direct emissions consisted of fossil $\mathrm{CO}_{2}$ from diesel combustion during turning and gaseous emissions from degradation of the waste material. These have been measured at the site (Andersen et al., 2009) and the GWF of the direct emissions was $119 \mathrm{~kg}$ $\mathrm{CO}_{2}$-eq tonne ${ }^{-1} \mathrm{ww}\left(81 \mathrm{~kg} \mathrm{CO}\right.$-eq tonne ${ }^{-1} \mathrm{ww}$ for $\mathrm{CH}_{4}$ emissions, $30 \mathrm{~kg} \mathrm{CO}$-eq tonne ${ }^{-1}$ ww for $\mathrm{N}_{2} \mathrm{O}$ emissions and $8 \mathrm{~kg} \mathrm{CO}_{2}$-eq tonne ${ }^{-1} \mathrm{ww}$ from diesel combustion). The indirect upstream emissions were minor and only related to provision of diesel and electricity and added up to $1.2 \mathrm{~kg} \mathrm{CO}_{2}$-eq tonne ${ }^{-1} \mathrm{Ww}$.

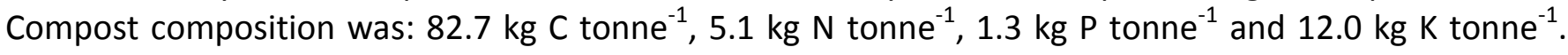
The substitution ratios were assumed to be $20 \%$ for N, $100 \%$ for $P$ and $100 \%$ for K. Substitution of mineral fertilizers would save emissions in the order 7.3-25.7 $\mathrm{kg} \mathrm{CO}_{2}$-eq tonne ${ }^{-1} \mathrm{ww} . \mathrm{N}_{2} \mathrm{O}$ emissions from application of compost on land were assumed to be $1.4 \%$ of the applied nitrogen, equivalent to $51.3 \mathrm{~g}$ $\mathrm{N}_{2} \mathrm{O}$ tonne ${ }^{-1}$ ww (i.e. $15.3 \mathrm{~kg} \mathrm{CO}_{2}$-eq tonne ${ }^{-1} \mathrm{ww}$ ). Carbon binding was $14 \%$, i.e. $30.6 \mathrm{~kg} \mathrm{CO}_{2}$-eq tonne ${ }^{-1}$ ww treated were saved. In modelling peat substitution, it was estimated that 1 tonne of compost could replace $292 \mathrm{~kg}$ of peat and $970 \mathrm{~kg} \mathrm{CO}_{2}$-eq tonne ${ }^{-1}$ were emitted during the life cycle of peat utilization (Boldrin et al., 2009b). Considering the mass loss, savings from peat substitution were thus in the order of $192 \mathrm{~kg} \mathrm{CO}_{2}$-eq tonne ${ }^{-1} \mathrm{ww}$. An emission of $51.3 \mathrm{~g} \mathrm{~N}_{2} \mathrm{O}$ tonne $\mathrm{e}^{-1} \mathrm{ww}$ from compost degradation was here also assumed. The results are summarized in Table 14.

Table 4 summarizes the two examples representing different technologies (enclosed vs. open) and different waste types (biowaste vs. garden waste). Different indirect upstream GWFs reflect the lower use of energy in open systems, whilst the GWFs of the direct emissions demonstrate the benefits of treating the exhaust in enclosed systems. Greater savings from fertilizer substitution in the Dutch case are due to both a higher content of nutrients in biowaste and the higher utilization rate for nitrogen assumed in that specific study compared with the Danish case. Results for peat substitution are similar, despite different assumptions. 
Table 11 - Greenhouse gas account and global warming contribution for open composting technologies (values expressed per tonne of wet waste (ww) composted).

\begin{tabular}{|c|c|c|}
\hline Indirect: Upstream & Direct: Waste Management & Indirect: Downstream \\
\hline $\begin{array}{c}\left.\text { GWF (kg CO }{ }_{2} \text {-eq tonne }{ }^{-1} \mathrm{ww}\right): \\
0.2 \text { to } 4.4 \text { (low) } \\
0.2 \text { to } 20 \text { (high) }\end{array}$ & $\begin{array}{c}\left.\text { GWF ( } \mathrm{kg} \mathrm{CO}_{2} \text {-eq tonne } \mathrm{e}^{-1} \mathrm{ww}\right): \\
3 \text { to } 242\end{array}$ & $\begin{array}{c}\text { GWF (kg CO } \text { CO }_{2} \text { tonne } \\
-14 w w): \\
-145 \text { to }+19 \text { (use on land) } \\
-880 \text { to }+44 \text { (peat) }\end{array}$ \\
\hline $\begin{array}{l}\mathrm{CO}_{2} \text { - eq (kg tonne } \mathrm{e}^{-1} \mathrm{ww} \text { ): } \\
\text { Diesel provision: } 0.16 \text { to } 2.4 \\
\text { (GWP: } 1 \text { ) } \\
\text { Electricity provision (GWP: } 1 \text { ): } \\
\quad 0.002 \text { to } 2 \text { (low) } \\
\circ 0.02 \text { to } 18 \text { (high) }\end{array}$ & $\begin{array}{l}\left.\mathrm{CO}_{2} \text { - eq (kg tonne }{ }^{-1} \mathrm{ww}\right): \\
\text { - } \mathrm{CO}_{2} \text {-biogenic: } 0 \text { (GWP: } 0 \text { ) } \\
\text { - } \mathrm{CH}_{4} \text { emissions: } 0.8 \text { to } 169 \text { (GWP: } \\
25 \text { ) } \\
\text { - } \mathrm{N}_{2} \mathrm{O} \text { emissions: } 2.2 \text { to } 73 \text { (GWP: } \\
298 \text { ) } \\
\text { - } \mathrm{CO}_{2} \text {-fossil from diesel } \\
\text { combustion: } 1 \text { to } 16 \text { (GWP: } 1 \text { ) }\end{array}$ & $\begin{array}{l}\mathrm{CO}_{2} \text { - eq (kg tonne }{ }^{-1} \text { waste): } \\
\text { - Use on land: } \\
\text { - Provision of diesel: } 0.1 \text { to } 0.25 \\
\text { (GWP: } 1 \text { ) } \\
\text { - } \mathrm{CO}_{2} \text {-fossil from diesel } \\
\text { combustion: } 0.5 \text { to } 1.6 \\
\text { (GWP: } 1 \text { ) } \\
\text { - } \mathrm{CO}_{2} \text {-biogenic: } 0 \text { (GWP: 0) } \\
\text { - Mineral fertilizer substituted: } \\
-4 \text { to -81 (GWP: } 1 \text { ) } \\
\text { - } \mathrm{N}_{2} \mathrm{O} \text { emissions: }-42 \text { to } 88 \text { (GWP: } \\
298 \text { ) } \\
\text { - Carbon binding: }-2 \text { to }-79 \\
\text { (GWP: -1) } \\
\text { - OR } \\
\text { - Peat substitution: } \\
\text { - Peat substitution: }-44 \text { to }-838 \\
\text { (GWP: } 1 \text { ) } \\
\text { - } \mathrm{N}_{2} \mathrm{O} \text { emissions: }-42 \text { to } 88 \text { (GWP: } \\
\text { 298) }\end{array}$ \\
\hline $\begin{array}{l}\text { Accounted: } \\
\text { - Provision of diesel: } 0.4 \text { to } 6.0 \text { I } \\
\text { - Provision of electricity: } 0.02 \text { to } \\
19.7 \text { kWh }\end{array}$ & $\begin{array}{ll}\text { Accounted (unit tonne } & -1 \mathrm{ww} \text { ): } \\
\text { - } & \mathrm{CO}_{2} \text {-biogenic: } 43 \text { to } 413 \mathrm{~kg} \\
\text { - } & \mathrm{CH}_{4} \text { from process: } 0.03 \text { to } 6.8 \mathrm{~kg} \\
\text { - } & \mathrm{N}_{2} \mathrm{O} \text { from process: } 7.5 \text { to } 252 \mathrm{~g} \\
\text { - } & \text { Combustion of diesel: } 0.4 \text { to } 6.0 \text { । } \\
\text { - } & \text { Use of electricity: } 0.02 \text { to } 19.7 \\
& \text { kWh }\end{array}$ & $\begin{array}{l}\text { Accounted (unit tonne }{ }^{-1} \text { waste): } \\
\text { - Use on land: } \\
\text { - Combustion of diesel: } 0.2 \text { to } \\
0.6 \mathrm{I} \\
\text { - } \mathrm{CO}_{2} \text {-biogenic: } 220 \text { to } 1217 \mathrm{~kg} \\
\text { - Fertilizer substitution: } 0.5 \text { to } \\
5.2 \mathrm{~kg} \mathrm{~N}, 0.6 \text { to } 2.8 \mathrm{~kg} \mathrm{P}, 2.4 \\
\text { to } 9.7 \mathrm{~kg} \mathrm{~K} \\
\text { - } \mathrm{N}_{2} \mathrm{O} \text { emissions: }-0.14 \text { to } 0.3 \mathrm{~kg} \\
\text { - Carbon binding: } 1 \text { to } 22 \mathrm{~kg} \\
\quad \mathrm{OR} \\
\text { - Peat substitution: } \\
\text { - CO }{ }_{2} \text {-biogenic: } 92 \text { to } 566 \mathrm{~kg} \\
\text { - Peat substitution: } 80 \text { to } 700 \mathrm{~kg} \\
\text { - } \mathrm{N}_{2} \mathrm{O} \text { emissions: }-0.14 \text { to } 0.3 \mathrm{~kg}\end{array}$ \\
\hline $\begin{array}{l}\text { Not accounted: } \\
\text { - Construction of composting } \\
\text { facility } \\
\text { - Bulking agents } \\
\text { - Provision of other materials (oil, } \\
\text { detergents, lubricants etc.) }\end{array}$ & $\begin{array}{l}\text { Not accounted: } \\
\text { - Any trace gas release }\end{array}$ & $\begin{array}{l}\text { Not accounted: } \\
\text { - } \begin{array}{l}\text { Landscaping } \\
\text { substitution }\end{array} \\
\text { - } \quad \text { Incineration of screened } \\
\text { residues } \\
\text { - } \quad \text { Landfilling of screened residues } \\
\text { - } \quad \text { Landfilling of compost } \\
\text { Improved soil quality }\end{array}$ \\
\hline
\end{tabular}


Table 12 - Greenhouse gas account and global warming contribution for enclosed composting technologies (values expressed per tonne of wet waste (ww) composted).

\begin{tabular}{|c|c|c|}
\hline Indirect: Upstream & Direct: Waste Management & Indirect: Downstream \\
\hline $\begin{array}{c}\left.\text { GWF (kg } \mathrm{CO}_{2} \text {-eq tonne }{ }^{-1} \mathrm{ww}\right): \\
1 \text { to } 8 \text { (low) } \\
8.2 \text { to } 60 \text { (high) }\end{array}$ & $\begin{array}{c}\left.\text { GWF (kg CO }{ }_{2} \text {-eq tonne }{ }^{-1} \mathrm{ww}\right): \\
5 \text { to } 81\end{array}$ & $\begin{array}{c}\left.\text { GWF (kg CO } \text { CO }_{2} \text { tonne }{ }^{-1} \mathrm{ww}\right): \\
-145 \text { to }+19 \text { (use on land) } \\
-880 \text { to }+44 \text { (peat) }\end{array}$ \\
\hline $\begin{array}{l}\left.\mathrm{CO}_{2} \text { - eq (kg tonne }{ }^{-1} \mathrm{ww}\right): \\
\text { Diesel provision: } 0.05 \text { to } 1.2 \\
\text { (GWP: } 1 \text { ) } \\
\text { - Electricity provision (GWP: } 1 \text { ): } \\
\quad 0.9 \text { to } 6.5 \text { (low) } \\
\circ 8.1 \text { to } 58.5 \text { (high) }\end{array}$ & $\begin{array}{l}\mathrm{CO}_{2} \text { - eq }\left(\mathrm{kg} \text { tonne }{ }^{-1} \mathrm{ww}\right): \\
\left.\text { - } \mathrm{CO}_{2} \text {-biogenic: } 0 \text { (GWP: } 0\right) \\
\text { - } \mathrm{CH}_{4} \text { emissions: } 5 \text { to } 46 \\
\text { (GWP: 25) } \\
\text { - } \mathrm{N}_{2} \mathrm{O} \text { emissions: } 0.3 \text { to } 35 \text { (GWP: } \\
298 \text { ) } \\
\text { - } \mathrm{CO}_{2} \text {-fossil from } \\
\text { combustion: } 0.4 \text { to } 8.0 \text { (GWP: } \\
\text { 1) }\end{array}$ & $\begin{array}{l}\left.\mathrm{CO}_{2} \text { - eq (kg tonne }{ }^{-1} \mathrm{ww}\right) \text { : } \\
\text { - Use on land: } \\
\text { - Provision of diesel: } 0.1 \text { to } 0.25 \\
\text { (GWP: } 1) \\
\text { - } \mathrm{CO}_{2} \text {-fossil from diesel } \\
\text { combustion: } 0.5 \text { to } 1.6 \\
\text { (GWP: } 1) \\
\text { - } \mathrm{CO}_{2} \text {-biogenic: } 0 \text { (GWP: } 0 \text { ) } \\
\text { - Mineral fertilizer substituted: } \\
-4 \text { to -82 (GWP: } 1 \text { ) } \\
\text { - } \mathrm{N}_{2} \mathrm{O} \text { emissions: }-42 \text { to } 88 \text { (GWP: } \\
298) \\
\text { - Carbon binding: }-2 \text { to }-79 \\
\text { (GWP: }-1 \text { ) } \\
\text { - Peat substitution: } \\
\text { - } \mathrm{CO}_{2} \text {-biogenic: } 0 \text { (GWP: } 0 \text { ) } \\
\text { - Peat substitution: }-44 \text { to }-838 \\
\text { (GWP: } 1 \text { ) } \\
\text { - } \mathrm{N}_{2} \mathrm{O} \text { emissions: }-42 \text { to } 88 \text { (GWP: }\end{array}$ \\
\hline $\begin{array}{l}\text { Accounted: } \\
\text { - Provision of diesel: } 0.13 \text { to } 31 \\
\text { - Provision of electricity: } 9 \text { to } 65 \\
\text { kWh }\end{array}$ & $\begin{array}{l}\text { Accounted (unit tonne }{ }^{-1} \mathrm{ww} \text { ): } \\
\text { - } \quad \mathrm{CO}_{2} \text {-biogenic: } 250 \text { to } 390 \mathrm{~kg} \\
\text { - } \quad \mathrm{CH}_{4} \text { from process: } 0.2 \text { to } 1.8 \mathrm{~kg} \\
\text { - } \quad \mathrm{N}_{2} \mathrm{O} \text { from process: } 10 \text { to } 120 \mathrm{~g} \\
\text { - } \quad \text { Combustion of diesel: } 0.13 \text { to } 3 \mathrm{I} \\
\text { - } \quad \text { Use of electricity: } 9 \text { to } 65 \mathrm{kWh}\end{array}$ & $\begin{array}{l}\left.\text { Accounted (unit tonne }{ }^{-1} \mathrm{ww}\right): \\
\text { - Use on land: } \\
\text { - Combustion of diesel: } 0.2 \text { to } \\
0.6 \text { I } \\
\text { - } \mathrm{CO}_{2} \text {-biogenic: } 220 \text { to } 1217 \mathrm{~kg} \\
\text { - Fertilizer substitution: } 0.5 \text { to } \\
5.2 \mathrm{~kg} \mathrm{~N}, 0.6 \text { to } 2.8 \mathrm{~kg} \mathrm{P}, 2.4 \\
\quad \text { to } 9.7 \mathrm{~kg} \mathrm{~K} \\
\text { - } \mathrm{N}_{2} \mathrm{O} \text { emissions: }-0.14 \text { to } 0.3 \mathrm{~kg} \\
\text { - Carbon binding: } 1 \text { to } 22 \mathrm{~kg} \\
\quad \text { OR } \\
\text { - Peat substitution: } \\
\text { - } \mathrm{CO}_{2} \text {-biogenic: } 92 \text { to } 566 \mathrm{~kg} \\
\text { - Peat substitution: } 80 \text { to } 700 \mathrm{~kg} \\
\text { - } \mathrm{N}_{2} \mathrm{O} \text { emissions: }-0.14 \text { to } 0.3 \mathrm{~kg}\end{array}$ \\
\hline $\begin{array}{l}\text { Not accounted: } \\
\text { - Construction of composting } \\
\text { facility } \\
\text { - Bulking agents } \\
\text { - } \quad \text { Provision of other materials (oil, } \\
\text { detergents, lubricants etc.) }\end{array}$ & $\begin{array}{l}\text { Not accounted: } \\
\text { - } \quad \text { Any trace gas release }\end{array}$ & $\begin{array}{l}\text { Not accounted: } \\
\text { - } \quad \text { Landscaping } \\
\text { substitution: } \\
\text { - } \quad \text { Incineration of screened } \\
\text { residues } \\
\text { - Landfilling of screened residues } \\
\text { - Landfilling of compost } \\
\text { - } \quad \text { Improved soil quality }\end{array}$ \\
\hline
\end{tabular}


Table 13 - Greenhouse gas account and global warming contribution for home composting (values expressed per tonne of wet waste (ww) composted).

\begin{tabular}{|c|c|c|}
\hline $\begin{array}{c}\text { Indirect: Upstream } \\
\left.\text { GWF (kg CO} \text { CO }^{-e q} \text { tonne }^{-1} \mathrm{ww}\right): \\
0\end{array}$ & $\begin{array}{c}\text { Direct: Waste Management } \\
\left.\text { GWF (kg CO} \text { CO }_{2} \text {-eq tonne }{ }^{-1} \mathrm{ww}\right): \\
77 \text { to } 220\end{array}$ & $\begin{array}{l}\text { Indirect: Downstream } \\
\left.\text { GWF (kg CO } \text { CO }_{2} \text {-eq tonne }{ }^{-1} \mathrm{ww}\right): \\
-146 \text { to }+17 \text { (use on land) } \\
-880 \text { to }+44 \text { (peat) }\end{array}$ \\
\hline $\mathrm{CO}_{2^{-}}$eq $\left(\mathrm{kg}\right.$ tonne $\left.{ }^{-1} \mathrm{ww}\right):$ & $\begin{array}{l}\left.\mathrm{CO}_{2} \text { - eq (kg tonne }{ }^{-1} \mathrm{wW}\right): \\
\text { - } \mathrm{CO}_{2} \text {-biogenic: } 0 \text { (GWP: 0) } \\
\text { - } \mathrm{CH}_{4} \text { emissions: } 20 \text { to } 55 \text { (GWP: } \\
25 \text { ) } \\
\text { - } \mathrm{N}_{2} \mathrm{O} \text { emissions: } 57 \text { to } 165 \text { (GWP: } \\
298 \text { ) }\end{array}$ & $\begin{array}{l}\mathrm{CO}_{2} \text { - eq (kg tonne }{ }^{-1} \mathrm{wW} \text { ): } \\
\text { - Use on land: } \\
\text { - } \mathrm{CO}_{2} \text {-biogenic: } 0 \text { (GWP: 0) } \\
\text { - Mineral fertilizer substituted: } \\
-4 \text { to }-82 \text { (GWP: } 1 \text { ) } \\
\text { - } \mathrm{N}_{2} \mathrm{O} \text { emissions: }-42 \text { to } 88 \text { (GWP: } \\
\text { 298) } \\
\text { - Carbon binding: -2 to }-79 \\
\text { (GWP: }-1 \text { ) } \\
\text { OR } \\
\text { - Peat substitution: } \\
\text { - } \mathrm{CO}_{2} \text {-biogenic: } 0 \text { (GWP: } 0 \text { ) } \\
\text { - Peat substitution: }-44 \text { to }-838 \\
\text { kg (GWP: } 1 \text { ) } \\
\text { - } \mathrm{N}_{2} \mathrm{O} \text { emissions: }-42 \text { to } 88 \text { (GWP: } \\
\text { 298) }\end{array}$ \\
\hline Accounted: & $\begin{array}{l}\text { Accounted (unit tonne } \mathrm{e}^{-1} \mathrm{ww} \text { ): } \\
\text { - } \mathrm{CO}_{2} \text {-biogenic: } 139 \text { to } 215 \mathrm{~kg} \\
\text { - } \quad \mathrm{CH}_{4} \text { from process: } 0.8 \text { to } 2.2 \mathrm{~kg} \\
\text { - } \quad \mathrm{N}_{2} \mathrm{O} \text { from process: } 0.2 \text { to } 0.5 \mathrm{~kg}\end{array}$ & $\begin{array}{l}\text { Accounted (unit tonne }{ }^{-1} \mathrm{ww} \text { ): } \\
\text { - Use on land: } \\
\text { - } \mathrm{CO}_{2} \text {-biogenic: } 220 \text { to } 1217 \mathrm{~kg} \\
\text { - Fertilizer substitution: } 0.5 \text { to } \\
5.2 \mathrm{~kg} \mathrm{~N}, 0.6 \text { to } 2.8 \mathrm{~kg} \mathrm{P}, 2.4 \\
\text { to } 9.7 \mathrm{~kg} \mathrm{~K} \\
\text { - } \mathrm{N}_{2} \mathrm{O} \text { emissions: }-0.14 \text { to } 0.3 \mathrm{~kg} \\
\text { - Carbon binding: } 1 \text { to } 22 \mathrm{~kg} \\
\quad \mathrm{OR} \\
\text { - Peat substitution: } \\
\text { - } \mathrm{CO}_{2} \text {-biogenic: } 92 \text { to } 566 \mathrm{~kg} \\
\text { - Peat substitution: } 80 \text { to } 700 \mathrm{~kg} \\
\text { - } \mathrm{N}_{2} \mathrm{O} \text { emissions: }-0.14 \text { to } 0.3 \mathrm{~kg}\end{array}$ \\
\hline $\begin{array}{l}\text { Not accounted: } \\
\text { - Construction of plastic } \\
\text { composter and plastic bucket }\end{array}$ & $\begin{array}{l}\text { Not accounted: } \\
\text { - } \quad \text { Any trace gas release }\end{array}$ & Not accounted: \\
\hline
\end{tabular}

Table 14 - Summary of two examples described in the text.

\begin{tabular}{|c|c|c|c|c|c|}
\hline Example & Technology & $\begin{array}{l}\text { Waste } \\
\text { type }\end{array}$ & $\begin{array}{l}\text { Indirect: } \\
\text { Upstream }\end{array}$ & $\begin{array}{c}\text { Direct: } \\
\text { Waste Management }\end{array}$ & $\begin{array}{c}\text { Indirect: } \\
\text { Downstream }\end{array}$ \\
\hline & & & $\begin{array}{c}\text { GWF } \\
\left(\mathrm{kg} \mathrm{CO}_{2} \text {-eq tonne }{ }^{-1} \mathrm{ww}\right)\end{array}$ & $\begin{array}{c}\mathrm{GWF} \\
\left.\text { (kg CO}_{2} \text {-eq tonne }{ }^{-1} \mathrm{ww}\right)\end{array}$ & $\begin{array}{c}\text { GWF } \\
\left(\mathrm{kg} \mathrm{CO}_{2} \text {-eq tonne }{ }^{-1} \mathrm{ww}\right)\end{array}$ \\
\hline Dutch LCA & $\begin{array}{ll}86 & \% \\
\text { enclosed } & \\
\text { facilities } & \end{array}$ & $\begin{array}{l}\text { Household } \\
\text { biowaste }\end{array}$ & $\begin{array}{l}3.2 \text { (low) } \\
28.8 \text { (high) }\end{array}$ & 35 & $\begin{array}{c}-22.4 \text { to }-46.1 \text { (fertilizer) } \\
-169 \text { (peat) }\end{array}$ \\
\hline $\begin{array}{l}\text { Århus } \\
\text { assessment }\end{array}$ & $\begin{array}{l}\text { Windrow } \\
\text { composting }\end{array}$ & $\begin{array}{l}\text { Garden } \\
\text { waste }\end{array}$ & 1.2 & 119 & $\begin{array}{c}-22.6 \text { to }-41 \text { (fertilizer) } \\
-177 \text { (peat) }\end{array}$ \\
\hline
\end{tabular}




\section{Conclusions}

The GHG accounting for composting of organic waste shows that the contribution to GW depends on several factors, suggesting that the overall emission factor for composting may vary between significant savings (-800 kg CO 2 -eq tonne $\left.{ }^{-1} \mathrm{ww}\right)$ to a net load (300 kg CO $\mathrm{CO}_{2}$-eq tonne $\left.{ }^{-1} \mathrm{ww}\right)$. Significant factors are offgas cleaning at the composting plant (only possible for enclosed systems) and the use of the compost. The major savings are obtained by use of compost as a substitute for peat in the production of growth media. Garden waste composting generates the most compost per tonne of waste composted and thus may obtain the most savings.

The survey and methodological approach shows how GHGs can be counted for composting. Upstream activities contribute very little and the direct contributions from the composting plant are moderate, in particular if the off-gasses from the facility are treated prior to discharge. The main loads and main savings - and often the latter exceed the former - come from the use of the compost. Although the cases presented shows how these contributions can be calculated, the estimates are associated with extensive uncertainty. Often the use of the compost and what the compost substitutes for are not well known. The principal issues are known but no statistics are available. In addition, the release of $\mathrm{N}_{2} \mathrm{O}$ from the compost as it is being used is not well documented and, similarly, the avoided emissions are not well quantified: some authors suggest net savings of $\mathrm{N}_{2} \mathrm{O}$ when using compost instead of mineral fertilizers, some others report loads to the environment. The main learning may be that it is extremely important that the compost is used in a rational way substituting for the production and use of other materials (fertilizer and peat) in order to obtain the global warming benefits of composting organic waste.

\section{Acknowledgments}

Authors would like to particularly thank Tina Benfield (UK), Jean Bogner (USA), Enzo Favoino (IT), Henning Friege (DE) and Tjalfe Poulsen (DK) for the precious comments they provided during the preparation of the manuscript. 


\section{References}

Amlinger, F., Peyr, S. \& Cuhls, C. (2008) Greenhouse gas emissions from composting and mechanical biological treatment. Waste Management \& Research, 26, 47-60.

Andersen, J.K., Boldrin, A., Samuelsson, J., Christensen, T.H., \& Scheutz, C. (2009) Quantification of gaseous emissions from windrow composting of garden waste. In preparation.

Astrup, T., Møller, J., Fruergaard, T. \& Christensen, T.H. (2009) Incineration and co-combustion of waste: Accounting of greenhouse gases and global warming contributions. Waste Management \& Research, Special Issue XXXX.

Audsley, E., Alber, S., Clift, R., Cowell, S., Crettaz, P., Gaillard, G., Hausheer, J., Jolliet, O., Kleijn, R., Mortensen, B., Pearce, D., Roger, E., Teulon, H., Weidema, B. \& Zeijts, H.v. (1997) Harmonization of environmental life cycle assessment for agriculture. AIR3-CT94-2028, Community Research and Technological Development Programme in the field of 'Agriculture and Agro-Industry, including Fisheries' AIR 3, European Commission DG VI Agriculture, Brussels, Belgium.

Baky, A., \& Eriksson, O. (2003) Systems analysis of organic waste management in Denmark. Miljøstyrelsen, Copenhagen, Denmark.

Ballestero, T.P., \& Douglas, E.M. (1996) Comparison between the nitrogen fluxes from composting farm wastes and composting yard wastes. Transactions of the ASAE, 39, 1709-1715.

Barton, J.R., Issaias, I. \& Stentiford, E.I. (2008) Carbon - Making the right choice for waste management in developing countries. Waste Management, 28, 690-698.

Beck-Friis, B., Pell, M., Sonesson, U., Jönsson, H. \& Kirchmann, H. (2000) Formation and Emission of N2O and $\mathrm{CH} 4$ from Compost Heaps of Organic Household Wastes. Environmental Monitoring and Assessment, 62,317-331.

BGKeV, Bundesgütegemeinschaft Kompost e.V. (2007) Data on average composition of compost in Germany. Personal communication.

Bjarnadottir, H.J., Fridriksson, G.B., Johnsen, T. \& Sletnes, H. (2002) Guidelines for the Use of LCA in the Waste Management Sector. Nordtest Report TR 517. Nordtest, Espoo, Finland.

Boldrin, A. (2007) LCA report: Miljøvurdering af haveaffald i Herning Kommune (Environmental assessment of garden waste management in Herning Kommune, in Danish). Institute of Environment \& Resources, Technical University of Denmark, Kgs. Lyngby, Denmark.

Boldrin, A., Andersen, J.K. \& Christensen, T.H. (2009a) Miljøvurdering af haveaffald i Århus Kommune. (LCA report: Environmental assessment of garden waste management in Århus Kommune, inn Danish). Department of Environmental Engineering, Technical University of Denmark, Kgs. Lyngby, Denmark. 
Boldrin, A., Hartling, K.R., Smidt, M.M. \& Christensen, T.H. (2009b) Use of compost and peat in growth media preparation: an environmental comparison using LCA-modelling (EASEWASTE). Submitted to Journal of Environmental Quality.

Brinkmann, A.F., van Zundert, E. \& Saft, R.J. (2004) Herziening levenscyclusanalyse voor GFT-afval: herberekening LCA bij het MER LAP (Revised life cycle analysis for VGF-waste: new LCA calculation of the EIA National Waste Management Policy Plan). Grontmij/IVAM, De Bilt/Amsterdam, The Netherlands.

Bruun, S., Hansen, T.L., Christensen, T.H., Magid, J. \& Jensen, L.S. (2006) Application of processed organic municipal solid waste on agricultural land: a scenario analysis. Environmental Modeling and Assessment, 11, 251-265.

Cabaraban, M.T.I., Khire, M.V. \& Alocilja, E.C. (2008) Aerobic in-vessel composting versus bioreactor landfilling using life cycle inventory models. Clean Technologies and Environmental Policy, 10, 39-52.

Chen, T.C. \& Lin, C.F. (2008) Greenhouse gases emissions from waste management practices using Life Cycle Inventory model. Journal of Hazardous Materials, 155, 23-31.

Christensen, T.H., Gentil, E., Boldrin, A., Larsen, A.W., Weidema, B.P. \& Haushild, M.Z. (2009) C balance, carbon dioxide emissions and global warming potentials in LCA-modeling of waste management systems. Waste Management \& Research, Special Issue XXXX.

Chung, Y.C. (2007) Evaluation of gas removal and bacterial community diversity in a biofilter developed to treat composting exhaust gases. Journal of Hazardous Materials, 144, 377-385.

Clemens, J. \& Cuhls, C. (2003) Greenhouse Gas Emissions from Mechanical and Biological Waste Treatment of Municipal Waste. Environmental Technology, 24, 745-754.

Crowe, M., Nolan, K., Collins, C., Carty, G. \& Donlon, B. (2002) Biodegradable municipal waste management in Europe. Copenhagen. EEA, Jan. 2002, 3v., 122 p.(EEA topic report, 15).

Dalemo, M., Son, U., Jönsson, H. \& Björklund, A. (1998) Effects of including nitrogen emissions from soil in environmental systems analysis of waste management strategies. Resources, conservation and Recycling, 24, 363-381.

Dalemo, M., Sonesson, U., Bjorklund, A., Mingarini, K., Frostell, B., Jonsson, H., Nybrant, T., Sundqvist, J.O. \& Thyselius, L. (1997). ORWARE - A simulation model for organic waste handling systems. Part 1: Model description. Resources, Conservation and Recycling, 21, 17-37.

EEC (1991) Council Directive 91/676/EEC of 12 December 1991 concerning the protection of waters against pollution caused by nitrates from agricultural sources. Official Journal of the European Communities, L 375, 31 December, 1-8. 
EASEWASTE (2008). Database of EASEWASTE 2008, Version 4:5:001. Department of Environmental Engineering, Technical University of Denmark, Kgs. Lyngby, Denmark.

EC - European Commission (2006) Reference document on Best Available Techniques for the waste treatments industries. JRC, Sevilla, Spain.

ECN - European Composting Network (2008) Personal communication with Josef Barth, Managing Director.

Edelmann, W., Schleiss, K. \& Joss, A. (2000) Ecological, energetic and economic comparison of anaerobic digestion with different competing technologies to treat biogenic wastes. Water Science and Technology, 41, (3), 263-274.

Eggleston, S., Buendia, L., Miwa, K., Ngara, T. \& Tanabe, K. (2006) IPCC Guidelines for National Greenhouse Gas Inventories. Vol. 5 Waste. IPCC National Greenhouse Gas Inventories Programme, Institute for Global Environmental Strategies, Hayama, Kanagawa, Japan. Accessed February 2009 from: http://www.ipcc-nggip.iges.or.jp/public/2006gl/

Eisted, R., Larsen, A.W. \& Christensen, T.H. (2009) Collection, transfer and transport of waste: Accounting of greenhouse gases and global warming contributions. Waste Management \& Research, Special Issue XXXX.

Eklind, Y., Beck-Friis, B., Bengtsson, S., Ejlertsson, J., Kirchmann, H., Mathisen, B. \& Nordkvist, E. (1997) Chemical characterization of source-separated organic household wastes. Swedish Journal of Agricultural Research, 27, 167-178.

Favoino, E., and Hogg, D. (2008). The potential role of compost in reducing greenhouse gases. Waste Management \& Research 26: 61-69.

Finnveden, G., Johansson, J., Lind, P., \& Moberg, Å. (2000) Life cycle assessments of energy from solid waste; 2000. Stockholm, (http://www.infra.kth.se/fms/).

Fisher, K. (2006) Impact of Energy from Waste and Recycling Policy on UK Greenhouse Gas Emissions Final Report. Prepared by Environment Resource Management (ERM) for Department for Environment, Food and Rural Affairs (DEFRA), Oxford, UK. Accessed February 2009 from: http://randd.defra.gov.uk/Document.aspx?Document=WR0609_5737_FRP.pdf

Fruergaard, T., Ekvall, T. \& Astrup, T. (2009) Energy use and recovery in waste management and implications for accounting of greenhouse gases and global warming. Waste Management \& Research, Special Issue XXXX.

Gentil, E., Aoustin, E. \& Christensen, T.H. (2009) Waste management: Accounting of greenhouse gases and global warming contributions. Waste Management \& Research, Special Issue XXXX.

GEMIS. (2008) Database of GEMIS, Version 4.42, Institute for Applied Ecology, Berlin, Germany. 
Gronauer, A., Claassen, N., Ebertseder, T., Fischer, P., Gutser, R., Helm, M., Popp, L. \& Schön, H. (1997) Bioabfallkompostierung: Verfahren und Verwertung. Schriftenreihe Heft 139. Bayerisches Landesamt für Umweltschutz, München, Germany.

Güereca, L.P., Gassó, S., Baldasano, J.M. \& Jiménez-Guerrero, P. (2006) Life cycle assessment of two biowaste management systems for Barcelona, Spain. Resources, Conservation \& Recycling, 49, $32-48$.

Ham, R.K. \& D.P.Komilis, (2003) A Laboratory Study to Investigate Gaseous Emissions and Solids Decomposition During Composting of Municipal Solid Wastes. EPA-600/R-03/004. U.S. Environmental Protection Agency, Washington, DC, USA. Accessed February 2009 from: http://www.epa.gov/nrmrl/pubs/600r03004/600r03004.pdf

Hansen, T.L., Bhander, G.S., Christensen, T.H., Bruun, S. \& Jensen, L.S. (2006) Life cycle modelling of environmental impacts of application of processed organic municipal solid waste on agricultural land (EASEWASTE). Waste Management \& Research, 24, 153.

Hansen, T.L., La Cour Jansen, J., Spliid, H., Davidsson, Å. \&Christensen, T.H. (2007) Composition of source-sorted municipal organic waste collected in Danish cities. Waste Management, 27, 510518.

Haug, R.T. (1993) The Practical Handbook of Compost Engineering. CRC Press, Boca Ranton, FL, USA.

He, Y., Inamori, Y., Mizuochi, M., Kong, H., Iwami, N. \& Sun, T. (2001) Nitrous Oxide Emissions from Aerated Composting of Organic Waste. Environmental Science \& Technology, 35, 2347-2351.

Hellebrand, H.J. (1998) Emission of Nitrous Oxide and other Trace Gases during Composting of Grass and Green Waste. Journal of Agricultural Engineering Research, 69, 365-375.

Hogg, D., Barth, J., Favoino, E., Centemero, M., Caimi, V., Amlinger, F., Devliegher, W., Brinton, W. \& Antler, S. (2002) Comparison of Compost Standards within the EU, North America and Australasia. The Waste and Resources Action Programme (WRAP) Banbury, Oxon, UK.

ICF Consulting. (2005) Determination of the Impact of Waste Management Activities on Greenhouse Gas Emissions: 2005 Update Final Report. Environment Canada and Natural Resources Canada, Toronto, Canada.

Komilis, D.P. \& Ham, R.K. (2004) Life-Cycle Inventory of Municipal Solid Waste and Yard Waste Windrow Composting in the United States. Journal of Environmental Engineering, 130, 1390-1400.

Kranert, M. \& Gottschall, R. (2007) Grünabfälle - besser kompostieren oder energetisch verwerten? EdDE-Dokumentation Nr. 11, Entsorgergemeinschaft der Deutschen Entsorgungswirtschaft e.V., Köln, Germany.

Liamsanguan, C., \& Gheewala, S.H. (2008) The holistic impact of integrated solid waste management on greenhouse gas emissions in Phuket. Journal of Cleaner Production, 16: 1865-1871 
Manfredi, S., Scharff, H., Barlaz, M., Tonini, D. \& Christensen, T.H. (2009). Landfilling of waste: Accounting of greenhouse gases and global warming contributions. Waste Management \& Research, Special Issue XXXX.

Marb, C., Dietrich, G., Köbernik, M. \& Neuchl, C. (1997). Vergleichende Untersuchungen zur Kompostierung von Bioabfällen i Reaktoren und auf Mieten: Emissionen, Qualität und Schadstoffe. Müll und Abfall, 29, 609-620.

Marmo, L. (2008) EU strategies and policies on soil and waste management to offset greenhouse gas emissions. Waste Management, 28, 685-689.

Mathur, S.P., and Voisin, B. (1996). The use of compost as greenhouse growth media. Final Report of a Study Conducted for Waste Reduction Branch, Ontario Ministry of Environment and Energy at the Composting Council of Canada.

NIRAS A/S (2004) Madaffald fra storkøkkener. Arbejdsrapport fra Miljøstyrelsen Nr. 1, 2004 Miljøstyrelsen, Copenhagen, Denmark.

Powelson, D.K., Chanton, J., Abichou, T. \& Morales, J. (2006) Methane oxidation in water-spreading and compost biofilters. Waste Management \& Research, 24, 528-536.

Prasad, M. \& Maher, M.J. (2006) Evaluation of composted botanic material as components of a reducedpeat growing media for nursery stock. In: Proceedings of the International Conference ORBIT 2006: Biological Waste Management. From Local to Global. Weimar, 13-15 September. Verlag ORBIT e.V , Weimar, Germany.

Recycled Organics Unit (2003) Life Cycle Inventory and Life Cycle Assessment for Windrow Composting Systems. Report prepared for NSW Department of Environment and Conservation (Sustainability Programs Division), Published by Recycled Organics Unit, The University of New South Wales, Sydney, Australia.

Schleiss, K. (2007) Data on average composition of compost in Switzerland in 2005-2006. Personal communication.

Siebert, S. (2006): personal communication with Stefanie Siebert, Bundesgütegemeinschaft Kompost e.V. (BGKeV). Data on average composition of compost in Germany in 2006.

Smith, A., Brown, K., Ogilvie, S., Rushton, K. \& Bates, J. (2001) Waste Management Options and Climate Change. Final report to the European Commission, DG Environment. AEA Technology. Office for Official Publications of the European Communities,, Luxembourg.

Solomon, S., D. Qin, M. Manning, Z. Chen, M. Marquis, K.B. Averyt, M. Tignor \& H.L. Miller (eds.) (2007) Climate Change 2007. The physical science basis. Contribution of working group 1 to the fourth assessment report of the intergovernmental panel on climate change. Cambridge University Press, Cambridge, UK. 
Tchobanoglous, G. (1993) Integrated solid waste management: engineering principles and management issues. McGraw-Hill, New York, NY, USA.

UNFCCC. (2006) Approved baseline and monitoring methodology AM0025. Avoided emissions from organic waste through alternative waste treatment processes. Clean Development Mechanisms, United nations Framework Conventionn on Climate Change, Bonn, Germany.

USEPA (2006) Solid Waste Management and Greenhouse Gases: A Life-cycle Assessment of Emissions and Sinks. 3rd Ed. US Environmental Protection Agency, Washington, DC, USA. Accessed February 2009 from:

http://www.epa.gov/climatechange/wycd/waste/downloads/fullreport.pdf

Vogt, R., Knappe, F., Griegrich, J. \& Detzel, A. (2002) Ökobilanz Bioabfallverwertung: Untersuchungen zur Umweltverträglichkeit von Systemen zur Verwertung von biologisch-organischen Abfällen. Erich Schmidt, Berlin, Germany.

Ward, C., Litterick, A. \& Stephen, N. (2005) Assessment of the Potential for Site and Seasonal Variation of Composted Material Across the UK. WRAP, Banbury, UK.

Williams, P.T. (2005) Waste Treatment and Disposal. 2nd edition. John Wiley \& Sons Ltd, Chicester, UK.

Wood, S., and Cowie, A. (2004). A review of greenhouse gas emission factors for fertiliser production. IEA Bioenergy Task 38.

Zhao, W., van der Voet, E., Zhang, Y., \& Huppes, G. (2009) Life cycle assessment of municipal solid waste management with regard to greenhouse gas emissions: Case study of Tianjin, China. Science of the Total Environment, 407: 1517-1526. 